\title{
Subsidence and uplift mechanisms within the South Caspian Basin: insights from the onshore and offshore Azerbaijan region
}

\author{
STUART S. EGAN ${ }^{*}$, JON MOSAR ${ }^{2}$, MARIE-FRANÇOISE BRUNET $^{3,4} \&$ \\ TALAT KANGARLI ${ }^{5}$ \\ ${ }^{1}$ School of Physical and Geographical Sciences, Keele University, Keele, Staffordshire \\ ST5 $5 B G, U K$ \\ ${ }^{2}$ Département de Géosciences de l'Université, Géologie et Paléontologie, Pérolles-Ch du \\ Musée 6, CH-1700 Fribourg, Switzerland \\ ${ }^{3}$ UPMC Université Paris 06, UMR Tectonique, case 129, 4, place Jussieu, \\ F-75005 Paris, France \\ ${ }^{4}$ CNRS, UMR Tectonique, F-75005 Paris, France \\ ${ }^{5}$ Geology Institute of Azerbaijan, National Academy of Sciences, H. Javid av. 29A, \\ Baku AZ1143, Azerbaijan.
}

\begin{abstract}
A combination of fieldwork, basin analysis and modelling techniques has been used to try and understand the role, as well as the timing, of the subsidence-uplift mechanisms that have affected the Azerbaijan region of the South Caspian Basin (SCB) from Mesozoic to Recent.

Key outcrops have been studied in the eastern Greater Caucasus, and the region has been divided into several major tectonic zones that are diagnostic of different former sedimentary realms representing a complete traverse from a passive margin setting to slope and distal basin environments. Subsequent deformation has caused folds and thrusts that generally trend from NW-SE to WNW-ESE.

Offshore data has been analysed to provide insights into the regional structural and stratigraphic evolution of the SCB to the east of Azerbaijan. Several structural trends and subsidence patterns have been identified within the study area. In addition, burial history modelling suggests that there are at least three main components of subsidence, including a relatively short-lived basin-wide event at $6 \mathrm{Ma}$ that is characterized by a rapid increase in the rate of subsidence.

Numerical modelling that includes structural, thermal, isostatic and surface processes has been applied to the SCB. Models that reconcile the observed amount of fault-controlled deformation with the magnitude of overall thinning of the crust generate a comparable amount of subsidence to that observed in the basin. In addition, model results support the tectonic scenario that SCB crust has a density that is compatible with an oceanic composition and is being under-thrust beneath the central Caspian region.
\end{abstract}

Some of the deepest sedimentary basins, and largest sources of hydrocarbons, in the world occur within intra-continental settings, but they are poorly understood in terms of the mechanisms that have controlled their subsidence history. The South Caspian Basin (SCB) is an example of one of these deep basins (Fig. 1), with a depth to basement of over $20 \mathrm{~km}$ in places (Shikalibeily \& Grigoriants 1980; Brunet et al. 2003). Although it is widely accepted that the SCB was initiated by Mesozoic back-arc extension related to the subduction of the Tethys Plate (e.g. Zonenshain \& Le Pichon 1986), more than half of the $20 \mathrm{~km}$ subsidence presently observed occurred within the tectonic framework of the evolution of the Alpine-Himalayan orogenic belt. The main focus of this investigation has been to attempt to decipher the role played by various subsidence and uplift mechanisms that have affected the SCB region from Mesozoic to Recent.

A combination of fieldwork, basin analysis and numerical modelling techniques has been used to compare and contrast structural styles, stratigraphic architecture and subsidence-uplift history of the SCB region. The investigation has concentrated on the Azerbaijan region of the basin (Fig. 1), mainly due to data availability. Key outcrops have been studied in the eastern Greater Caucasus, including the central part, its termination with the Caspian 


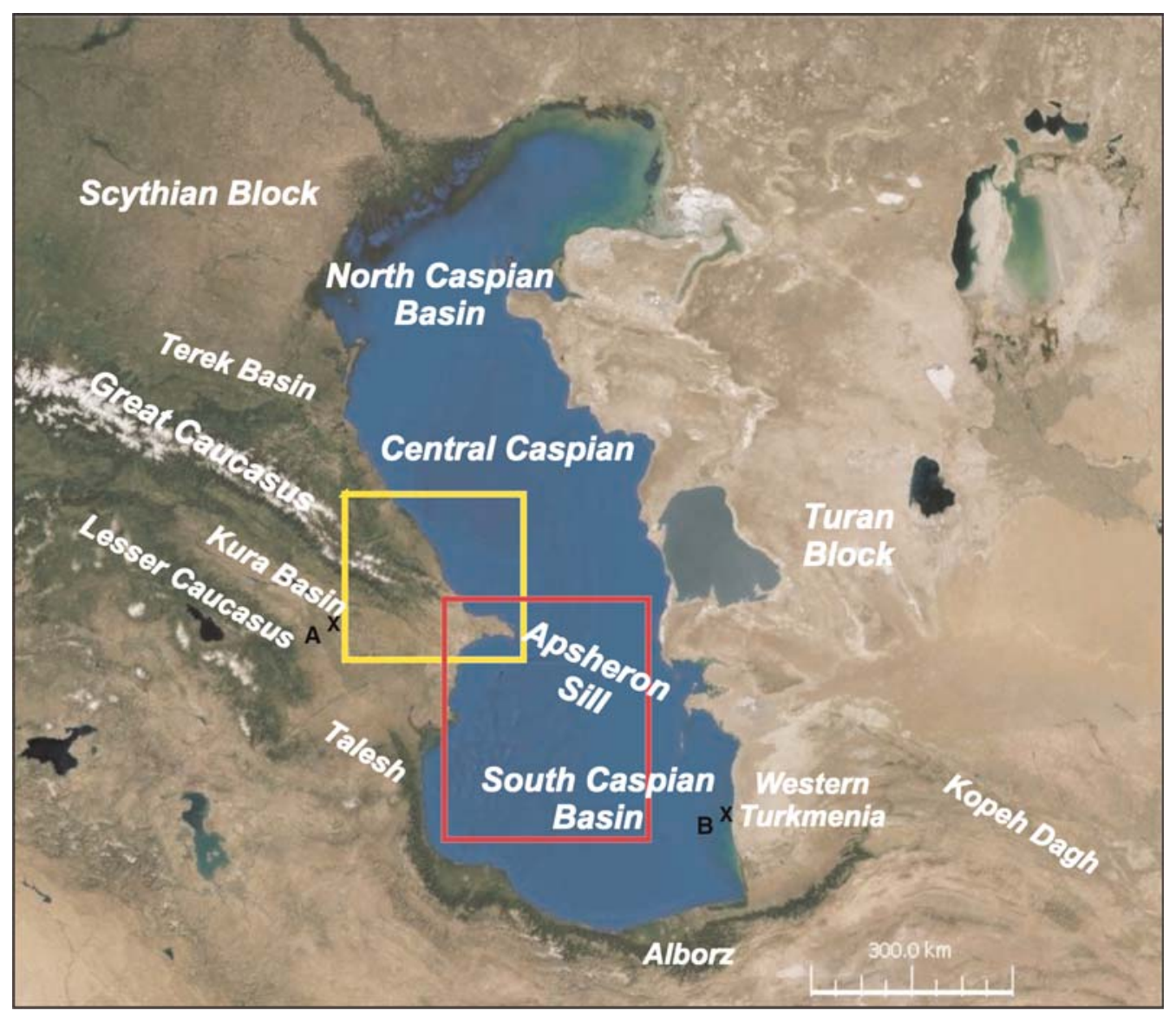

Fig. 1. Map of SCB and surrounding regions showing general location of onshore (yellow box) and offshore (red box) study areas (background image courtesy of NASA World Wind). Points A and B define the ends of the cross-section presented in Figure 2.

Sea, and the northern and southern fold-and-thrust fronts. The overall geodynamic setting of the eastern Greater Caucasus corresponds to a region of continental collision that has inverted former passive margin. The tectonic features are compatible with those of a doubly verging mountain belt with two external fold and thrust belts. One of the main objectives of the fieldwork has been to gather structural data from outcrops of various stratigraphic ages located at the SCB margins, as well as within the neighbouring Greater Caucasus orogenic belt. This structural investigation has been complemented by a sedimentological analysis to provide insights into the dominant depositional environments during the basin's evolution. The region is divided into several major tectonic zones that are diagnostic of different former sedimentary realms representing a complete traverse from a passive margin-type setting, with sediments from lagoonal to reef environments, to slope and distal basin environments. The onshore component of this study has provided a precise overview of the structure, stratigraphy and tectonic evolution of the eastern Greater Caucasus along a NNE-SSW transect, which can be used as a proxy for the evolution of the neighbouring SCB.

A number of regional-scale cross-sections and horizon depth maps, constructed from public domain and commercial exploration data, have been used to carry out a basin analysis exercise on the offshore Azerbaijan region of the SCB. The crosssections provide information on the regional structural and stratigraphic evolution of the SCB, while horizon depth maps have enabled the identification of regional and temporal structural trends. In particular, the map data show the close spatial relationship between the Apsheron Sill (Fig. 1) and the deepest parts of the basin. In addition, burial history modelling has been used to determine trends in subsidence 
within different parts of the study area. This modelling reveals several distinct subsidence events that have affected the basin, including a relatively shortlived basin-wide event at $6 \mathrm{Ma}$ that is characterized by a rapid increase in the rate of subsidence.

Structural and geodynamic modelling has been applied to the SCB that enables the forward modelling of extensional basin evolution due to rifting followed by subsequent deformational events. A kinematic modelling approach has been used, whereby a section of lithosphere is defined in terms of its thickness, density and thermal structure. Once the lithosphere is defined it is possible to numerically model its deformation via structural, thermal and isostatic processes (e.g. Egan \& Meredith 2007). This modelling is particularly useful for providing insights into the effects of deep-lithosphere processes that are not well constrained by geological and geophysical data. It has been used to test a variety of tectonic scenarios for SCB evolution, including depthdependent stretching and the possibility that the SCB crust has a density that is compatible with an oceanic-type composition.

\section{Geological background and evolution of the South Caspian Basin}

The SCB occupies the deep southern part of the Caspian Sea, and extends onshore in West Turkmenia in the east and the Lower Kura in the west (see Fig. 1 for location). It is one of the deepest basins in the world, with an estimated depth to basement of 20-25 km (e.g. Shikalibeily \& Grigoriants 1980; Zonenshain \& Le Pichon 1986; Brunet et al. 2003). The northern boundary of the SCB lies along the Apsheron Sill, a structural high that links to the Apsheron peninsula and the eastern Greater Caucasus. The Greater Caucasus orogenic belt was formed by compressional deformation resulting from the closure of a Jurassic-Eocene back-arc basin (e.g. Zonenshain \& Le Pichon 1986; Ershov et al. 1999).

The tectonic history of the region is dominated by folding and thrusting generated by the convergence between the Arabian and Eurasian plates. Recent seismic activity suggests that the SCB is behaving as a rigid block surrounded by weaker seismically active regions (Jackson et al. 2002; Allen et al. 2003). In addition, regional convergence of Arabia and Eurasia has resulted in a series of arcuate folds in the west of the basin that curve from the NWSE trend of the eastern Greater Caucasus, Apsheron Sill and Alborz regions, to an approximately northsouth trend to the west and east of the basin. These folds are mainly anticlinal buckle folds, which mostly detach within the mud-dominated deposits of the Maikop Suite (Allen et al. 2003). A linear, NW-SE-trending zone of folds in the north of the basin forms the Apsheron Sill, a topographically elevated region that is thought to be related to the under-thrusting of the SCB beneath the central Caspian basin.

There remains controversy regarding the timing of the opening of the SCB and whether there are two different sub-basins or only one. The majority of authors advocate that the SCB is a back-arc basin that formed in the Mesozoic (e.g. Zonenshain \& Le Pichon 1986). The opening of the Greater Caucasus back-arc basin started at the end of the Triassic and continued throughout the Jurassic (Ershov et al. 2003). A similar late Triassic-lower Jurassic timing is proposed for rifting in the proto-SCB (Brunet et al. 2003, 2007). Golonka (2000, 2004) proposes that the opening of the SCB took place in several stages from the Jurassic to the Eocene, and even as late as the Miocene in the southern part of the basin. Other authors, using data from the Talesh area (see Fig. 1 for location), propose that the main phase of opening of the SCB occurred during the Eocene (Kazmin 1991) or that there was opening of a southern trough near the Alborz at this time (Mamedov 2004). It has also been suggested that the SCB could be a remnant of the Palaeotethys Ocean (Berberian 1983) and that its relatively great depth is a result of subduction of continental crust during the mid-late Cenozoic (Knapp et al. 2000, 2004). The age of the oldest deposits in the deep central basin are not known. Part of the sedimentary sequence has been determined from onshore drilling in Azerbaijan and Turkmenistan where shallow-water sediments ranging from Late Jurassic to Pleistocene age have been found (Shikalibeily et al. 1988; Mamedov 1992; Ali-Zade et al. 1999; Knapp et al. 2004). The majority of the sedimentary infill of the SCB is Oligocene and younger.

The Maikop Suite forms the main hydrocarbon source rock in the SCB. The suite is dominated by mud-based sediments deposited from the Oligocene to the Miocene that have been subject to overpressuring as a result of rapid deposition of overlying sediments. They are commonly found at the surface at selected onshore localities where they form mud volcanoes (e.g. Guliyev \& Feizullayev 1997; Devlin et al. 1999). The Productive Series forms the main reservoir unit in the basin and is $5-7 \mathrm{~km}$ thick in the centre of the basin. The series consists of late Miocene-early Pliocene fluvial and deltaic deposits (Reynolds et al. 1998; Allen et al. 2003; Green et al. 2009).

The thickest component of the basin infill is represented by sequences of Pliocene-Quaternary in age (Fig. 2), where more than $10 \mathrm{~km}$ of sediment were deposited in less than $5 \mathrm{Ma}$ (Brunet et al. 2003); this represents an average depositional rate of approximately $2 \mathrm{~km} \mathrm{Ma}^{-1}$ for the last $5 \mathrm{Ma}$ (Knapp et al. 2004). Zonenshain \& Le Pichon 


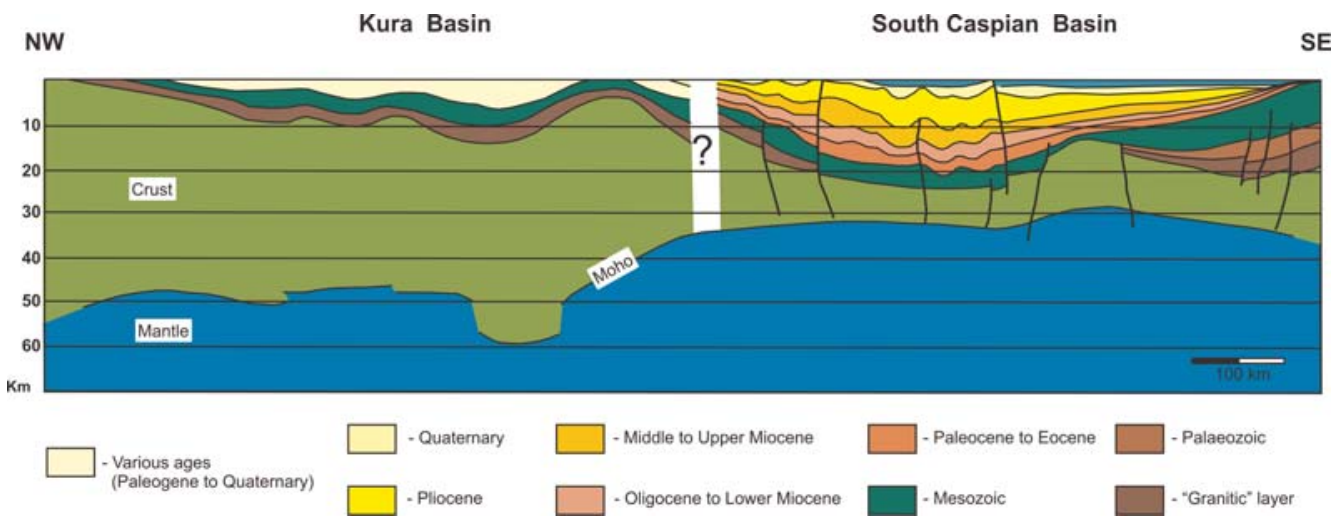

Fig. 2. Regional crustal-scale cross-section through the Kura and South Caspian basins (adapted from Baranova et al. 1991; Mamedov 1992). See Figure 1 for location.

(1986) and Nadirov et al. (1997) have suggested that these rapid rates of deposition were due to enhanced tectonic subsidence as a result of compressive forces acting in the last $6 \mathrm{Ma}$ with the sediment supplied by erosion of the uplifted areas at the basin margins. Green et al. (2009), however, explain the increased rate of deposition as being due to a rapid fall in base level at the end of the Miocene related to the Messinian Salinity Crisis. The basin was infilled rapidly by clastic deposits from palaeo-river systems when sea level rose again during the Pliocene.

The depth to the Moho varies from about $60 \mathrm{~km}$, beneath the onshore South Caspian region, to approximately $30 \mathrm{~km}$ beneath the deepest part of the SCB (Fig. 2). Based on seismic velocity data, it has been suggested that the 'granitic' crustal layer is absent in the central part of the basin (Mangino \& Priestley 1998). This could be because the crust is of oceanic origin, although it is thicker than normal oceanic crust. Alternatively, it could be continental crust of which the upper section has been removed by erosion or faulting, or it could be thinned and intruded continental crust. It has also been suggested (Zonenshain \& Le Pichon 1986) that the crust beneath the SCB is of continental origin but has been subjected to high pressures and high temperatures, such that the granite rocks of the continental basement were metamorphosed to become eclogite. From earthquake studies the SCB crust appears to be a relatively rigid and aseismic block within the framework of the Alpine-Himalayan orogenic belt (Priestley et al. 1994), which is further evidence for a rheological difference between the crust of the SCB and that of the surrounding region (Mangino \& Priestley 1998). Currently, the general consensus, mainly derived from geophysical data and gravimetric modelling (e.g. Shikalibeily \&
Grigoriants 1980; Berberian 1983; Baranova et al. 1991; Mangino \& Priestley 1998), is that the basement of the marine part of the basin comprises a high-velocity, thin complex crust. Controversy remains on its exact nature; thin high-density continental crust or thickened oceanic crust.

Earthquakes of depths up to $80 \mathrm{~km}$ have been recorded beneath the Apsheron Sill region. Some authors consider this seismicity to be caused by bending and faulting of the SCB lithosphere as it subducts beneath the Apsheron Sill (Priestley et al. 1994). Mangino \& Priestley (1998) and Knapp et al. (2004) also suggest that shallow-thrust events along the Apsheron Sill and folding of the sedimentary basin fill indicate that the Apsheron Sill is overriding the subducting crust of the SCB basement. It has also been proposed that the SCB is under-thrusting along its southwestern margin beneath the Talesh and Alborz mountains based on evidence from shallow-angle thrusting (Berberian 1983; Allen et al. 2003). However, Guest et al. (2007) propose a crustal buckling mechanism to explain subsidence in the southern part of the SCB and its relationship to the magnitude of uplift in the neighbouring Alborz mountains in northern Iran.

\section{Tectonic and stratigraphic evolution of the eastern Greater Caucasus}

Key outcrops have been studied in the eastern Greater Caucasus in Azerbaijan, extending from the frontal thrust range bordering the Kura Basin to the south, to the trailing part of the mountain belt in the north and bordering the eastern Terek Basin, to the eastern limits of the Greater Caucasus along the shores of the Caspian Sea. The main objectives of this field-based investigation were to document the different levels of the stratigraphic 


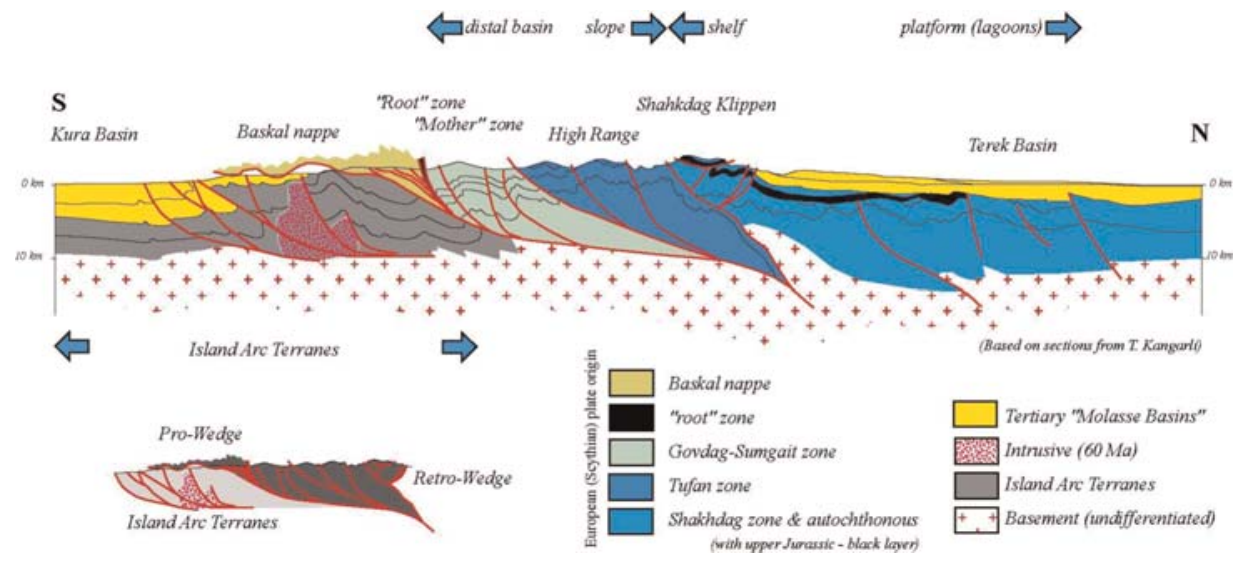

Fig. 3. Generalized tectonic cross-section through the central part of the eastern Greater Caucasus in Azerbaijan (adapted from Kangarli 1982). The major tectonic zones, and the northern and southern foreland basins, are shown. The tectonic zones also correspond to the major depositional realms, which from north to south are lagoon (restricted), reef/platform, proximal-distal slope (basinal), respectively.

column from Jurassic to present in order to understand the palaeotectonic evolution of the region.

The overall geodynamic setting of the eastern Greater Caucasus corresponds to a region of continental collision that has inverted the former passive margin of the Scythian Plate (Philip et al. 1989). To the south, volcanic material is derived from an active subduction-related volcanic arc in the Lesser Caucasus. The tectonic features of the eastern Greater Caucasus are compatible with those of a doubly verging mountain belt with two external fold-and-thrust belts (Fig. 3). The pro-wedge (front) is located to the south and overrides the Kura Basin, whereas the retro-wedge (back) is located to the north and overrides the eastern Terek Basin. The tectonic features and structural relationships are well exposed in the incised river valleys on the northern and southern slopes of the Greater Caucasus, but also in the steep slopes and cliffs of the higher central mountain range where the average altitude is above $2000 \mathrm{~m}$ and culminates at $4466 \mathrm{~m}$ with mount Bazar Düzü at the border between Azerbaijan and Dagestan.

Overall, the tectonic structure is one of a typical fold-and-thrust belt, with fault-related folding, thrusts, tectonic imbrications, tectonic klippen, relay structures, faulting and late transverse structures. The mountain-building tectonic events overprint structures that are related to syn-sedimentary palaeotectonics, both extensional and compressional (inversion). Folds and thrusts generally trend NWSE to WNW-ESE in the eastern Greater Caucasus, cleavage is axial-surface parallel and oriented WNW-ESE with steep-upright dips. Fold-axial surfaces are steep and dip to the north in the southern and central regions of the mountain range, showing a southwards vergence linked to a transport direction to the south in the frontal part of the mountain belt. Steep structures in the north part are associated with thrusting towards the north in the northern frontal part of the mountain range.

It has been possible to identify a succession of tectonic and sedimentary events within the eastern Greater Caucasus region based on data derived from the study of key outcrops. The oldest lithologies encountered are sedimentary sequences of Aalenian in age, located within the central range of the mountain belt. These sequences consist of interbedded shales and sandstones that formed within an extensional basin environment at the southern edge of the Scythian platform. North of the main fold-and-thrust belt, it is possible to observe sanddominated sequences at the base of the Lower Oxfordian resting with angular unconformity on folded Aalenian-Callovian sequences. An additional unconformity can be observed locally between the folded Callovian and the equally folded underlying Bathonian age units. A Jurassic-Cretaceous unconformity is represented by tilted Kimmeridgian beds overlain with erosive unconformity by Berriasian conglomerates that consist of clasts of Kimmeridgian limestone and Aalenian lithologies. The strong angular unconformity between conglomerates and the underlying Kimmeridgian-Tithonian sequences is interpreted to indicate fault-block tilting at the Jurassic-Cretaceous transition. The Valanginian-Barremian sequences are characterized by slump features and olistolith deposits. 
The olistoliths reach sizes of more than $200 \mathrm{~m}$ long and $35 \mathrm{~m}$ in thickness, and contain fragments of Jurassic limestone. The size and the repeated series of olistoliths suggest ongoing tectonic processes acting upon the carbonate platform forming the edge of the Scythian Plate. Folding and thrusting in the late Albian (pre-Turonian) led to the development of an erosive unconformity followed by sedimentation of neo-autochthonous sequences. The beginning of this neo-autochthonous sequence is marked by a basal conglomeratic sequence of Turonian age in the east and Campanian age to the west.

The sequence of events summarized above represent the pre-mountain belt (i.e. pre-Greater Caucasus) evolution of the region that occurred within a back-arc basin setting in response to subduction of the Tethys Plate to the South. The deformational regime was one of extensional tectonics and passive subsidence interrupted by compressionalinversion events. Collision then occurred between Arabia and Eurasia, leading to the closure of this basin system followed by a sequence of mountainbuilding events. An Eocene erosional unconformity marks the beginning of the formation of the fold-and-thrust belt, with the main uplift of the mountain range starting in Mid-Miocene. This deformation continues to the present with ongoing folding and thrusting, and progressive propagation of the thrust front at the southern leading edge of the orogenic belt. In addition, a general brittle overprinting can be observed throughout the area. This brittle tectonic deformation is represented by transverse faults trending NNE-SSW to NE-SW that cut all existing structures. Similar trends can be found in the fold patterns offshore that have been associated with faults within the basement.

The chart provided in Figure 4 provides a visual summary of the tectonic and stratigraphic events that have affected the eastern Greater Caucasus region.

\section{The geological evolution of the South Caspian Basin: offshore Azerbaijan}

A basin analysis exercise has been carried out on the Azerbaijan region of the SCB (see Fig. 1 for location) using interpretations of offshore seismic data provided by BP. The raw data are based on

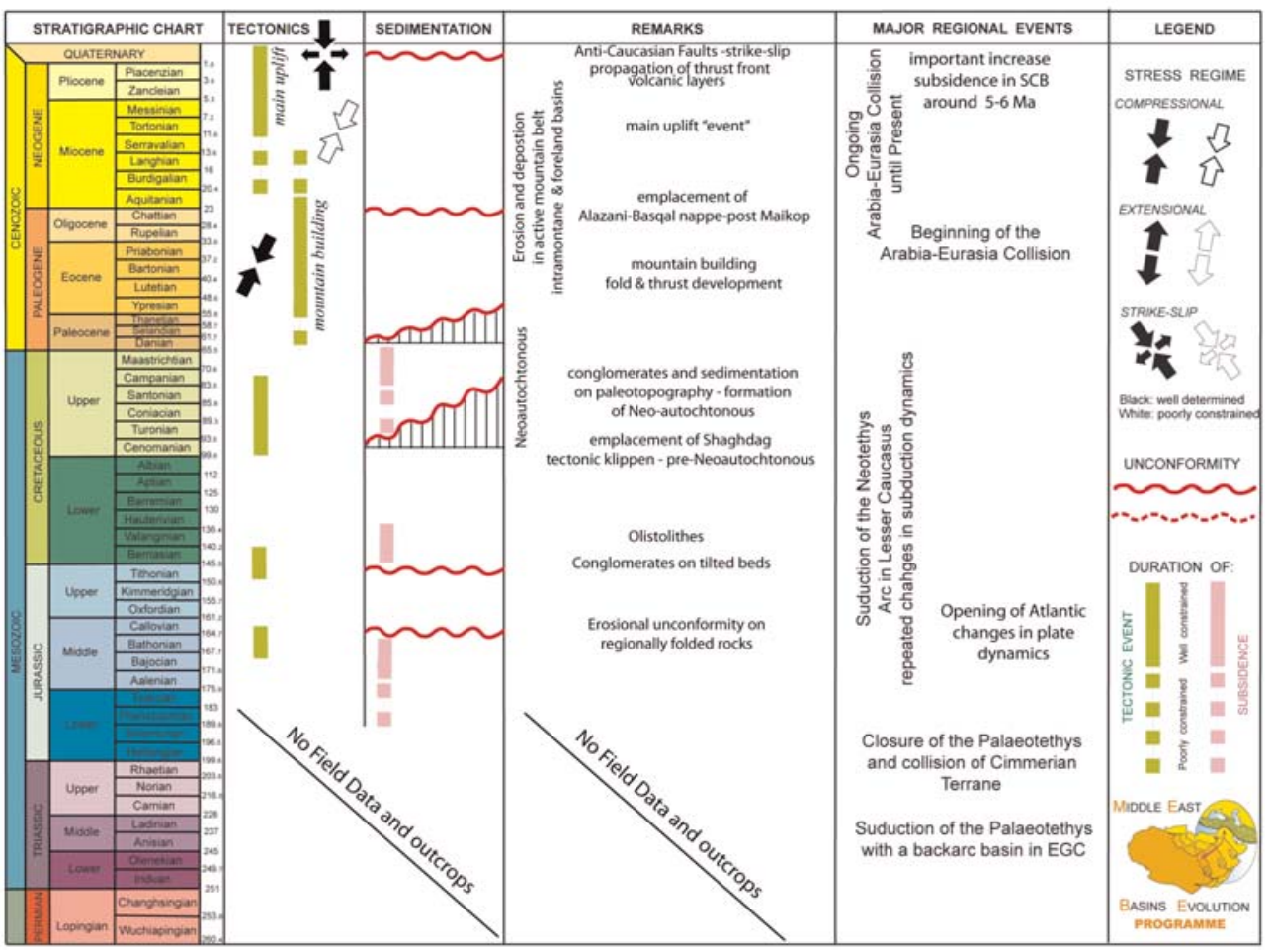

Fig. 4. Summary of the tectonic and stratigraphic evolution of the eastern Greater Caucasus produced from field-based investigation. Information on major regional events has been obtained from Zonenshain \& Le Pichon (1986), Philip et al. (1989) and Brunet et al. (2003). 
14 regional seismic lines that image down to $20 \mathrm{~s}$ TWT (two-way time). Depth maps have been produced for a number of stratigraphic horizons from 'basement' to Upper Pliocene, three of which are presented in Figure 5. These maps have been generated from depth-converted interpretations of the original seismic data (see, for example, the subsection on 'Data constraints and model parameters' later), which have been sampled and interpolated using a kriging algorithm to generate a regular grid across the study area, enabling contour maps to be generated. Analysis of the depth map for the Top Surakhany horizon (Upper Pliocene, dated at approximately 3.4 Ma; Devlin et al. 1999) reveals several structural trends and subsidence patterns (Fig 5a), including a relatively shallow-depth region with a NW-SE trend in the NE, where the horizon reaches depths of about $400 \mathrm{~m}$. This trend corresponds with the orientation of the Apsheron Sill, which has been formed by compressional deformation that affects Mesozoic-Recent sequences. It is also a trend that is compatible with onshore axial surfaces of the folds that are steep and dip to the north in the southern part of the Greater Caucasus mountain range. The deepest part of the horizon occurs adjacent to the Apsheron Sill where there is a depression reaching depths of about $4750 \mathrm{~m}$. This depression follows the southern margin of the Apsheron Sill and can be explained by flexural deepening due to under-thrusting or, possibly, subduction (Priestley et al. 1994; Granath et al. 2007) of South Caspian basement beneath the middle Caspian region.

The west of the map in Figure 5a shows a series of linear, relatively shallow features at depths of about $800-1200 \mathrm{~m}$. They have a NW-SE trend in the western part of the study area, changing to a more east-west trend in the southern part of the map where they also become more closely spaced. Interpretations of seismic data show that these features represent a set of closely spaced folds that mostly deform Maikop and younger sequences. Similar trends can be found in the fold patterns onshore. There is a NE-SW trend of linear highs that are most evident in the eastern part of the study area. These structures are more widely spaced than those with a NW-SE trend. In additiona, they do not reach the same shallow depths as the NW-SE-trending features. They have a similar trend to a set of transverse faults that cut all of the existing structures onshore. The horizon deepens towards the SE corner of the map where it has depths of 3000-3500 m. This deepening occurs towards the Pre-Alborz trough, which is located in the southeastern corner of the SCB as it approaches the Alborz orogenic belt.

Figure $5 \mathrm{~b}$ shows a similar depth map, but for the Top Mesozoic horizon. This map shows less area of coverage and detail compared to the younger horizon described above due to reduced quality and more limited coverage of the seismic data with increasing depth. The horizon in the main part of the study area has an average depth of about $11500 \mathrm{~m}$. The Apsheron Sill is, again, an area of relative uplift in the north at a depth of $7000 \mathrm{~m}$. Both NE-SW- and NW-SE-trending features are present with typical depths of about $9000 \mathrm{~m}$. However, they form broader features than in the younger horizons, which could be related to decoupling between pre- and post-Mesozoic strata or due to the superposition of folds with different wavelengths and amplitudes. In addition, there are linear regions of relative uplift with a north-south trend in the western part of the study area.

The depth to the Top Jurassic horizon is shown in Figure 5c. There is a broad, relatively shallow area in the south of the study area at depths of between 13000 and $15000 \mathrm{~m}$. Although the coverage of this map is limited, there is some evidence of uplift of the Apsheron Sill region, illustrated by a decrease in depth in the NE corner of the map to about $12000 \mathrm{~m}$. The deepest part of the area, at about $20000 \mathrm{~m}$, is again immediately to the south of the Apsheron Sill. However, this depression does not appear to continue as far to the west as it does in the younger horizons.

Burial history modelling is an important analytical technique that provides insights into the history of the deepening of a basin and therefore burial of the infilling sequences (Sclater \& Christie 1980). In addition, the burial history of a basin is indicative of the tectonic and isostatic processes operating at any particular time. Basin Mod 1-D software, produced by Platte River Associates, was used to construct burial history plots for selected locations within the SCB study area. It generates time v. depth plots that show the burial history of infill sequences within a basin through time, including the effects of tectonic subsidence, and burial and compaction due to the deposition of younger sequences. In order to carry out the modelling the software requires the ages and depths to each horizon as main input parameters. The lithological composition of each horizon was estimated based on evidence presented in the relevant literature and using Basin Mod 1-D's default lithology data. The locations selected for burial history analysis are shown in Figure 5a and were chosen for the following reasons:

- Location 1 was selected because it is located within the region of uplift forming the Apsheron Sill;

- Location 2 represents a relatively deep area of the basin margin in the NW; 
(a)

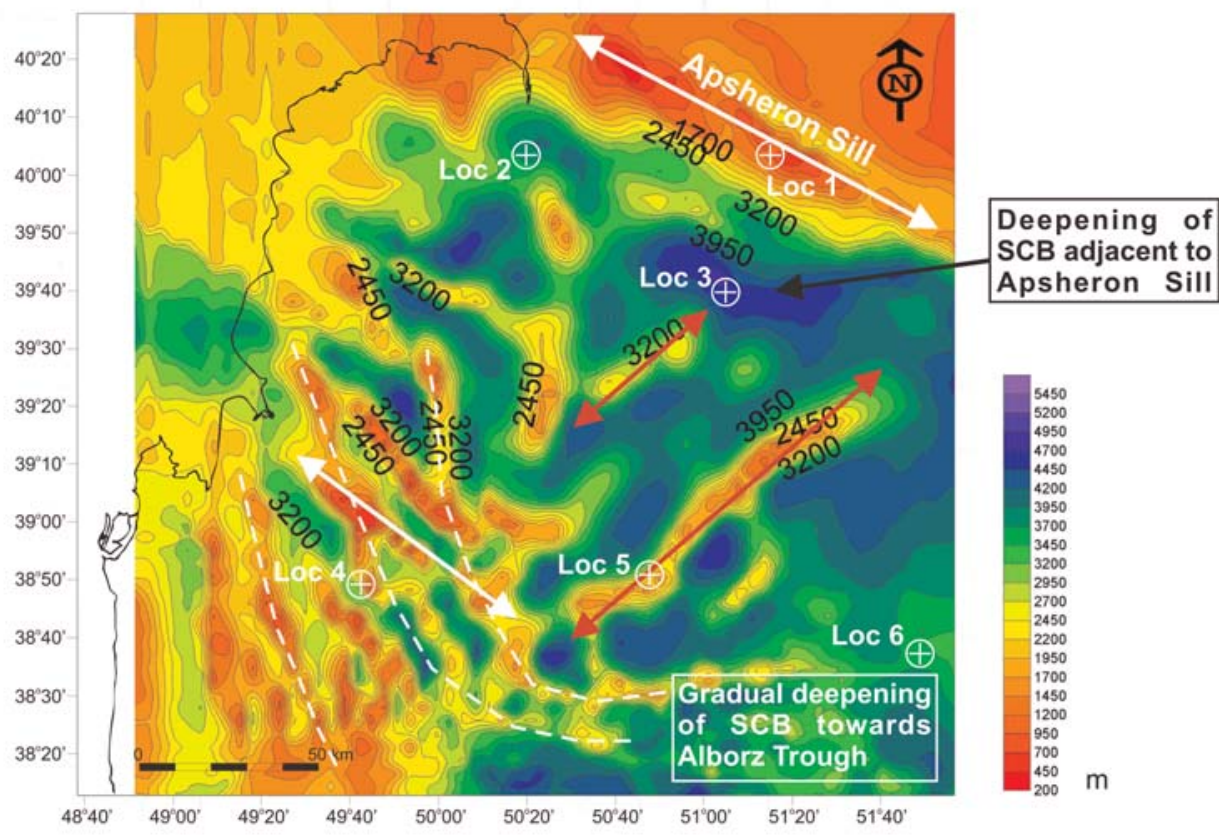

(b)

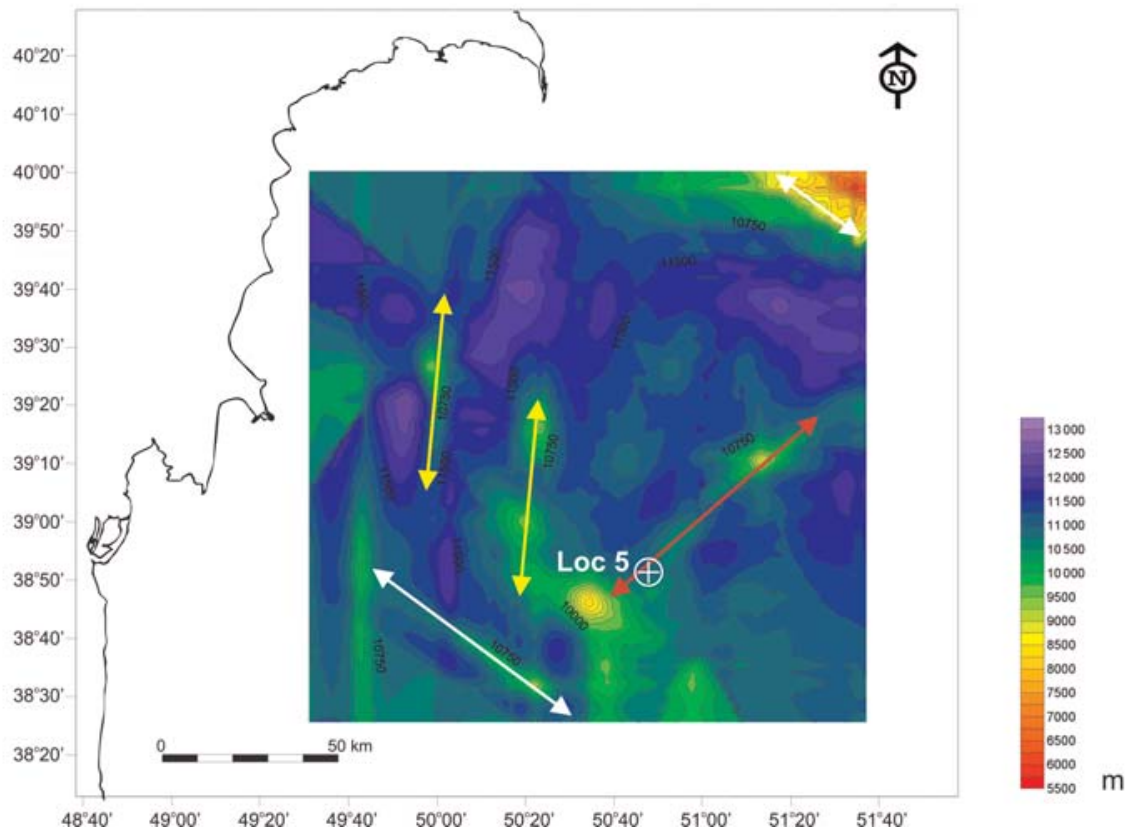

Fig. 5. Contour maps of depth to selected stratigraphic horizons within the SCB showing major structural trends (contours are at $250 \mathrm{~m}$ intervals). (a) Top Surakhany horizon (lower upper Pliocene). Labels 'Loc 1'- 'Loc 6' define the locations at which burial history analysis has been carried out (see Fig. 6). (b) Top Mesozoic horizon. (c) Top Jurassic horizon. 
(c)

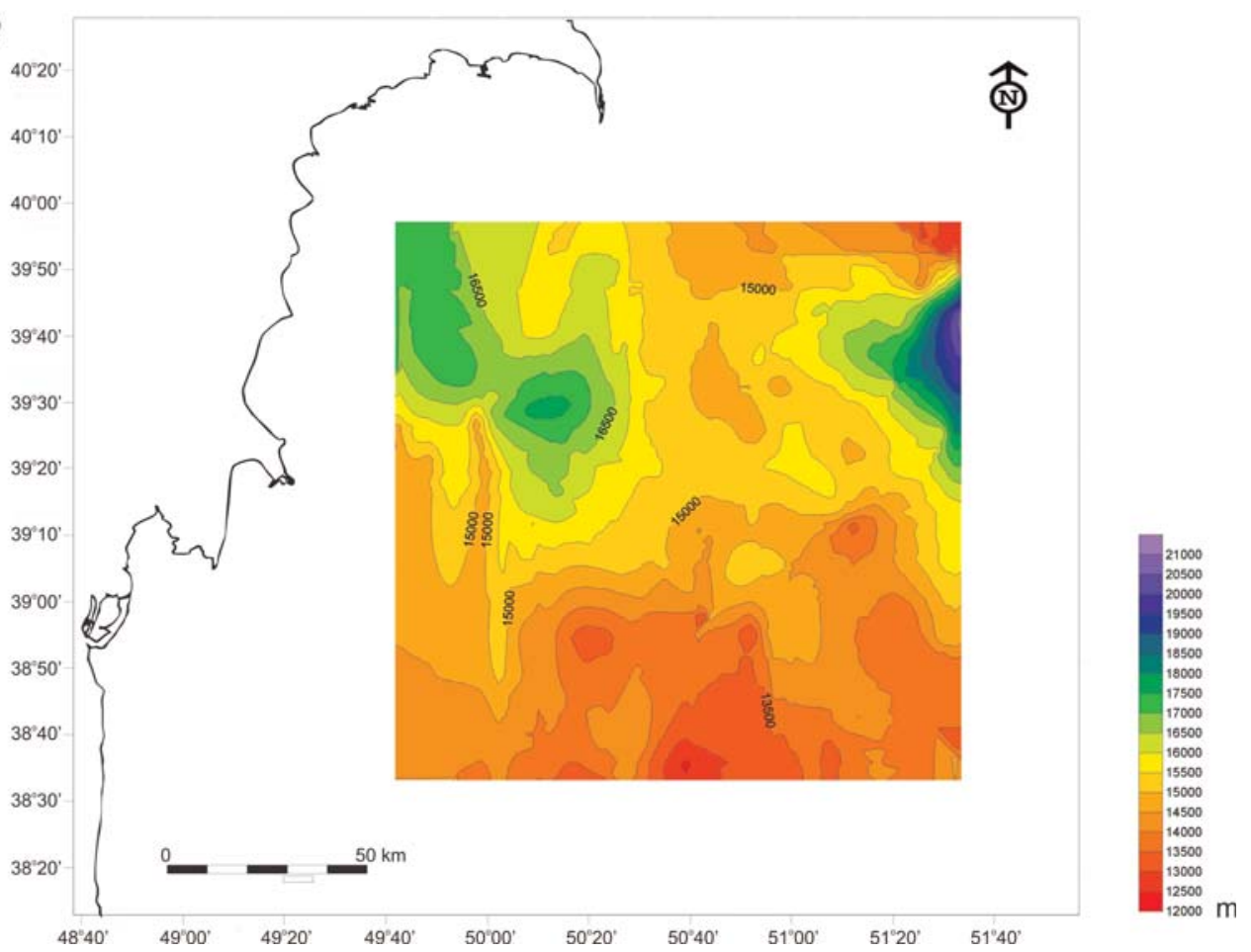

Fig. 5. Continued.

- Location 3 was selected to represent the deepest part of basin to the south of the Apsheron Sill;

- Location 4 lies on a NNW-SSE-trending high in the SW corner of the study area;

- Location 5 lies on a NE-SW-trending high in the centre of the basin;

- Location 6 was selected to represent the SE part of the study area where the basin deepens towards the Pre-Alborz trough.

The depths to major stratigraphic horizons were determined from the regional depth maps. It should be noted that the depth data were only available to the base of the Oligocene at most locations owing to the limited data coverage for the older sequences. Location 5, however, situated in the centre of the study area, has data for nine stratigraphic horizons from middle Cretaceous to upper Pliocene. The results from the burial history modelling (Fig. 6) suggest that there are at least three phases of subsidence. During the Cretaceous and most of the Palaeogene the basin exhibits gradual subsidence that decreases almost exponentially. This pattern of subsidence is compatible with a post-rift thermal subsidence phase, along with infill of the basin, following initial rifting of the $\mathrm{SCB}$ in the early-mid-Jurassic. This thermal

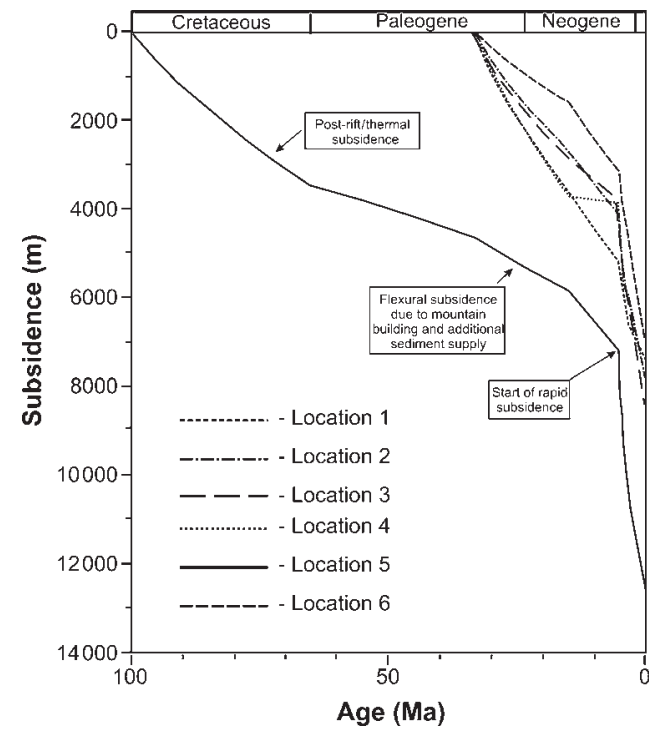

Fig. 6. Burial history modelling for locations 1-6 (see Fig. 5a for locations). At least three phases of subsidence can be identified. 
subsidence phase was disrupted at the beginning of the Oligocene when there was an increase in sedimentation rate. This change is likely to be generated by flexurally induced subsidence in response to sediment input from the mountain building occurring onshore. At the same time, compressional deformation affected the Apsheron Sill region. At about $6 \mathrm{Ma}$ the burial data shows a basin-wide event that is characterized by a rapid increase in the rate of sedimentation. The timing of this subsidence phase corresponds to the main uplift event identified onshore from field-based investigation and, therefore, is likely to result from flexural loading. The basin was infilled rapidly by an abundant supply of sedimentary material generated by erosion of the surrounding orogenic belts and a deep incision created by a short and local sea-level drop, equivalent to the Mediterranean Messinian event (Green et al. 2009).

\section{Subsidence mechanisms within the South Caspian Basin: insights from structural and geodynamic modelling}

Structural and geodynamic modelling has been applied to the SCB that enables the forward modelling of extensional basin evolution due to rifting followed by subsequent inversion events. The modelling is useful for testing the viability of a variety of tectonic scenarios that may explain the subsidence history of basins that are poorly constrained by subsurface data.

\section{Modelling approach}

A kinematic modelling approach has been used, whereby a section of lithosphere is defined in terms of its thickness, density and thermal structure. Once the lithosphere is defined its deformation is numerically modelled by the following geological and geodynamic processes.

\footnotetext{
Mechanical thinning or thickening of the crust due to movement along crustal faults. Thrust fault movement generates increased surface topography as well as constituting a downwards-acting load upon the lithosphere, which responds by flexing. In contrast, extensional faulting causes negative loading of the lithosphere and generates accommodation space in the form of graben formation. The fault configuration within the model is defined in terms of the number of faults required, and their relative spacing and orientation (i.e. synthetic or antithetic). All of the faults are assumed to terminate or detach at mid-lower crustal levels in order to maintain compatibility with evidence from deep seismic reflection data (e.g. Snyder \& Hobbs
}

1999), seismological investigations (e.g. Jackson \& McKenzie 1983) and rheological modelling of the lithosphere (e.g. Kusznir \& Park 1987). Movement along each of the faults is defined in terms of a heave value, and the amount of crustal thinning or thickening is calculated by using the Chevron or vertical shear construction (Verrall 1982; White et al. 1986). A listric fault geometry has been used within the modelling carried out in this study in order to simplify the model calculations. A more sophisticated flexural cantilever model based upon planar faults (e.g. Kusznir \& Egan 1989) would make little difference to model results at the scale of deformation being investigated here.

Mechanical thinning or thickening of both crust and mantle lithosphere by a regionally distributed pure shear mechanism. Deformation by a pure shear (i.e. stretching or squashing) mechanism is assumed to deform the more ductile sections of the lithosphere within the lower crust and mantle lithosphere (Kusznir et al. 1987). Both the lateral position and the width of the pure shear deformation can be defined.

Disturbances caused to the lithosphere temperature field. Lithosphere extension and compression causes an overall heating and cooling of the temperature field, respectively. For example, reverse movement along crustal faults causes the emplacement of relatively hot hanging-wall material onto that of a cool footwall, creating a cooling of the geotherm at shallow depth. Compressional deformation by pure shear thickens the lithosphere and also reduces the geothermal gradient. Within the model the lithosphere temperature field is represented as a twodimensional grid. Each node on the grid is assigned a pre-deformational temperature. The temperature of each grid node is then modified according to the amount of deformation experienced.

Re-equilibration of the temperature field after deformation. After a major tectonic event the lithosphere temperature field experiences a gradual thermal recovery. For example, in the context of extension the temperature field will cool back to an equilibrated state. The model calculates both lateral and vertical heat flux by the mechanism of conduction. The physical properties of the lithosphere are such that the thermal recovery process takes of the order of $100 \mathrm{ma}$.

Flexural isostatic compensation of tectonic loads. Crustal thinning and thickening, and thermal perturbations caused by tectonic activity, impose loads upon the lithosphere that have to pass through an isostatic filter to give a compensated amount of subsidence or uplift observed at the surface. The flexural isostatic response of the lithosphere to loading is 
calculated within the model in order to generate a realistic surface or basement profile and underlying crustal structure. The methodology used to model flexure assumes the lithosphere behaves as a continuous elastic plate, which is in equilibrium under the action of all applied loads (Turcotte \& Schubert 2002). The flexing properties of the lithosphere are defined by its flexural rigidity (Walcott 1970), which is, in turn, set in the model by the parameter effective elastic thickness $(\mathrm{Te})$.

Surface processes. The model contains simple algorithms to simulate the infill of accommodation space and the erosion of uplift. Isostatic adjustments are calculated in response to these processes such that sedimentary infill enhances subsidence within a basin, whereas erosion has the combined effect of reducing the size of the uplifts and unloading the lithosphere, which responds by regional isostatic uplift or rebound (Egan \& Urquhart 1993).

A comprehensive description of all theoretical aspects of the modelling approach are presented in Kusznir \& Egan (1989), Egan \& Urquhart (1993) and Egan \& Meredith (2007), and will not be repeated here. However, Figure 7 illustrates some of the parameters included in the model calculations and examples of results. A typical starting condition for the modelling is shown in Figure 7a, which illustrates a regional cross-section of undeformed lithosphere. The crustal component of this lithosphere is assumed to be $35 \mathrm{~km}$ thick with a density of $2800 \mathrm{~kg} \mathrm{~m}^{-3}$, while the mantle lithosphere is assumed to be $90 \mathrm{~km}$ thick with a density of $3300 \mathrm{~kg} \mathrm{~m}^{-3}$. The modelled lithosphere is thermally conditioned with an equilibrated geotherm, which has a surface temperature of $0{ }^{\circ} \mathrm{C}$ and a temperature at the lithosphere-asthenosphere boundary of $1333{ }^{\circ} \mathrm{C}$. All of these parameters can be varied according to the tectonic scenario to be modelled.

The effects of extending this lithosphere are shown in Figure $7 \mathrm{~b}$. The model shows how the crust has accommodated extensional deformation by movement along a sequence of faults, while the mantle lithosphere has been deformed by regionally distributed pure shear. The boundary between upper crustal deformation and that in the lower crust and mantle lithosphere is determined by a detachment depth, which is equivalent to the concept of necking depth presented by other authors (e.g. Kooi et al. 1992). The model shows a basement profile consisting of a sequence of closely spaced half-grabens with relative uplift of the footwall due to flexural isostatic processes (Weissel \& Karner 1989; Egan 1992). Extension has also caused heating of the lithosphere temperature field, which subsequently has cooled to generate gradual subsidence. The effects of this cooling can be seen in the model by a post-rift stratigraphic sequence that blankets the underlying fault blocks and syn-rift stratigraphy. Lithosphere shortening is represented by the model in Figure $7 \mathrm{c}$, which shows a 'piggy-back' style of thrusting adjacent to a foreland basin that has been generated mainly by flexure in response to crustal thickening caused by compressional tectonics. In addition, the modelling approach is sufficiently versatile to include multiple extensional and compressional events.

\section{Data constraints and model parameters}

Data constraint for the modelling is based on several regional cross-sections that have been generated from the interpretation of the original seismic data carried out by BP geoscientists to show structural and stratigraphic components. The cross-sections in Figure 8a and b show structural and stratigraphic components (in TWT) based upon the interpretation of two regional seismic lines acquired from SW to NE across the southern part of the study area. The section in Figure 8a begins about $125 \mathrm{~km}$ from the southern Azerbaijan coastline and continues NE for approximately $75 \mathrm{~km}$ into the central SCB; the precise location of this section is confidential. There is approximately $9 \mathrm{~km}$ of overlap between this cross-section and the SW part of the section in Figure 8b. The cross-sections show evidence of extensional faulting of basement; however, the magnitude of this extension appears to be quite small. In addition, there is evidence of fault-related compressional deformation in the NE part of the section shown in Figure $8 \mathrm{~b}$ that has uplifted Mesozoic and younger sequences to form the southern part of the Apsheron Sill. The thrust structures in this region appear to detach on or within basement, which is deepened significantly beneath the Apsheron Sill.

The cross-section presented in Figure 8c shows structural and stratigraphic components for part of the SCB, Apsheron Sill and Central Caspian Basin (CCB). It has been produced from interpretations of a number of seismic lines from these areas. The SW part of the section is dominated by shortwavelength buckle folds that die out about $60 \mathrm{~km}$ along the section at the start of the broad depression representing the central part of the SCB. This deep part of the basin is abruptly terminated by the Apsheron Sill, which forms a broad region of faultcontrolled uplift that has deformed CretaceousUpper Pliocene sequences. The thrusts in this area show vergence dominantly to the south. There is distinct thinning of Upper Pliocene (post-Top Surakhany) and Pleistocene sequences across the structure suggesting that this part of the Apsheron Sill has been experiencing uplift until very recently. The CCB is a much shallower structure compared to the SCB. For example, the Top Cretaceous 

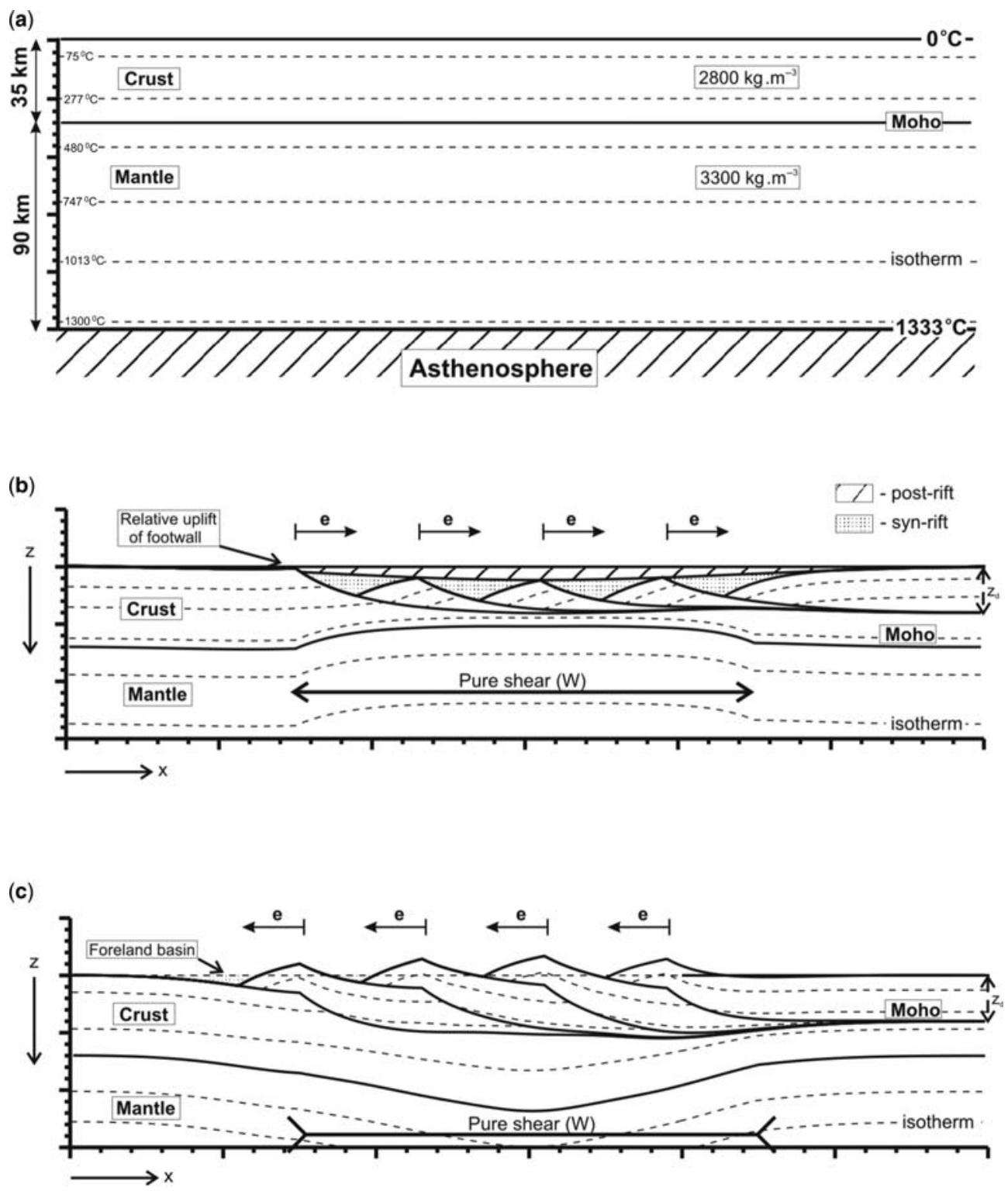

Fig 7. An integrated kinematic model of lithosphere deformation. (a) Cross-section of undeformed lithosphere showing initial values of parameters used in the model calculations. This model can be applied to simulate (b) lithosphere extension and associated basin formation, (c) lithosphere shortening and associated thrust-belt and foreland basin formation, or a combination of the two.

boundary reaches depths of $8.5 \mathrm{~s}$ TWT in the south compared to about $4 \mathrm{~s}$ TWT in the north. The Mesozoic sedimentary sequence is relatively thin, but shows localized thickening of Triassic sequences that is likely to have been caused by normal faulting and small-scale rifting events (Green et al. 2009). The CCB part of the section also shows a broad arch structure that is onlapped by post-Mesozoic sequences. The axis of this arch is located about $150 \mathrm{~km}$ to the north of the Apsheron Sill and can be interpreted as a flexural bulge structure generated in response to crustal thickening and loading created by the formation of the Apsheron Sill.

The SW-NE-oriented cross-sections shown in Figure $8 \mathrm{a}$ and $\mathrm{b}$ have been combined and depth-converted to give coverage over a distance 
(a)

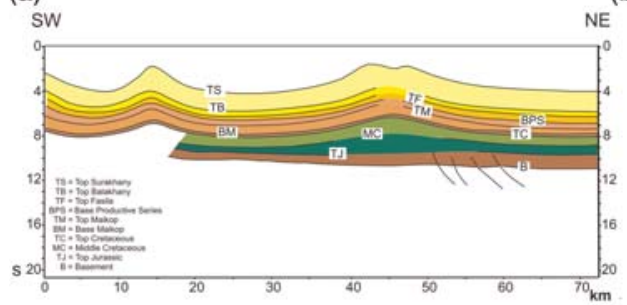

(b)

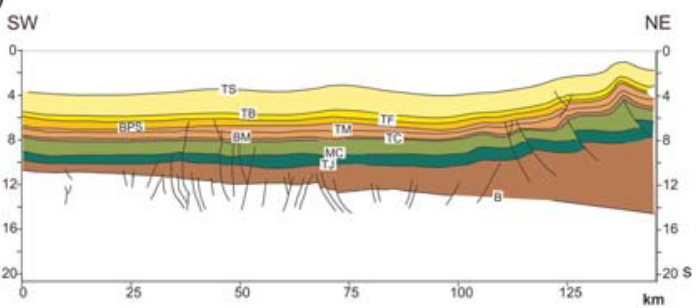

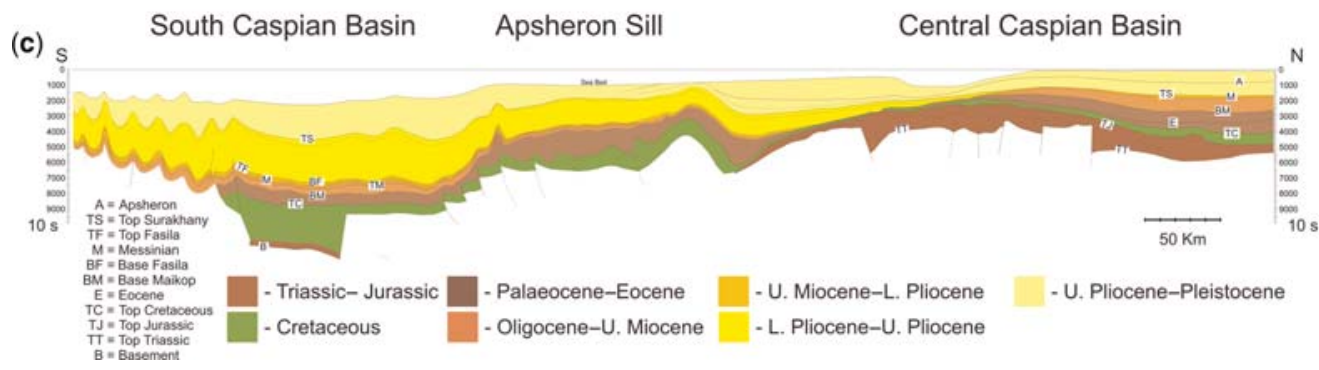

Fig. 8. (a) and (b) Cross-sections showing structural and stratigraphic components (in TWT) based on the interpretation of two overlapping regional seismic lines acquired from SW to NE across the study area. (c) Composite section across the SCB, Apsheron Sill and CCB.

of about $200 \mathrm{~km}$ from SW to NE of the offshore study area (Fig. 9a). One of the main input parameters required to carry out the modelling is quantification of the magnitude of deformation due to faulting. Each major fault is identified from the data in terms of its position. In addition, deformation is quantified as a positive or negative heave value, representing extension or compression, respectively. Figure $9 \mathrm{~b}$ and $\mathrm{c}$ show major extensional and compressional faults, and their magnitude of heave interpreted from the cross-sections presented in Figure 8.

\section{Model scenario 1 - uniform lithosphere deformation}

Figure 10 shows a model representation of the SCB and Apsheron Sill region, assuming evolution by regional uniform lithosphere deformation by a coupled faulting-pure shear process. The overall dimensions of the model are based on the regional sections presented in Figure 9, whereby major extensional faults observed in the cross-sections, along with the movement along them, have been reproduced in the model. Deformation by faulting is balanced to regionally distributed pure shear deformation (i.e. stretching) within the lower crust and mantle lithosphere to represent uniform lithosphere extension. Other model parameters, as well as assumptions made, include rifting is instantaneous; the original (i.e. pre-deformational) crustal thickness is assumed to be $35 \mathrm{~km}$; all faults have a surface dip of $45^{\circ}$ and are assumed to detach at a depth of $20 \mathrm{~km}$, below which the lower crust and mantle lithosphere deform by pure shear (Kusznir et al. 1987); accommodation is filled to sea level with sediment (average density of $2500 \mathrm{~kg} \mathrm{~m}^{-3}$ ); the density of the crust and mantle are assumed to be 2800 and $3300 \mathrm{~kg} \mathrm{~m}^{-3}$, respectively; lithosphere thickness is assumed to be $125 \mathrm{~km}$, with the basal boundary defined by the $1333{ }^{\circ} \mathrm{C}$ isotherm (McKenzie 1978). In addition, the flexural isostatic response of the lithosphere is constrained by an effective elastic thickness $(T e)$ of $5 \mathrm{~km}$ during rifting, and $10 \mathrm{~km}$ during the post-rift and compressional phases. These values are based on a sensitivity test of $T e$ in terms of it generating the most realistic combination of basin geometry and subsidence, and are also compatible with a number of extensional basin settings (e.g. Kusznir et al. 1991; Van Wees \& Cloetingh 1996).

Figure 10a represents the initial rift phase of the basin that is assumed to have occurred in the middle Jurassic. This timing is compatible with the Mesozoic origins of the proto-SCB as proposed by Golonka $(2000,2004)$ and Brunet et al. (2003). The model profile in Figure $10 \mathrm{~b}$ has simulated 
(a)

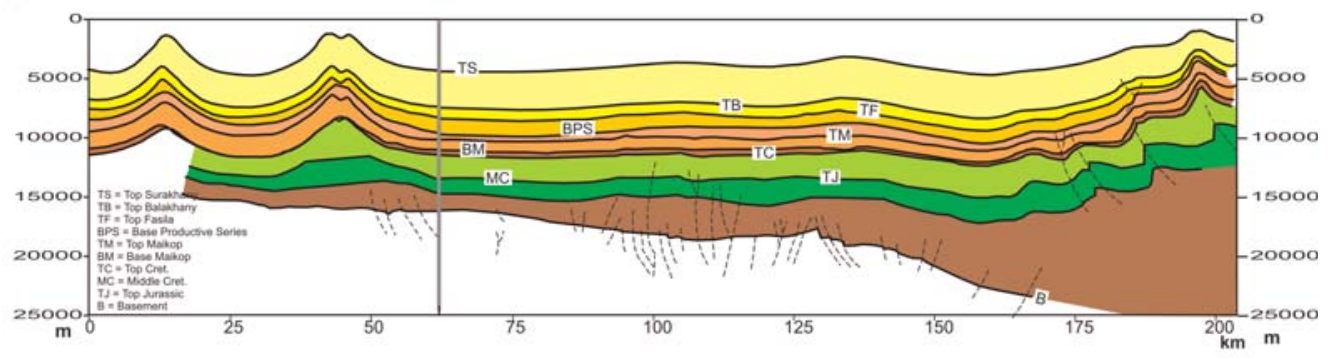

(b)

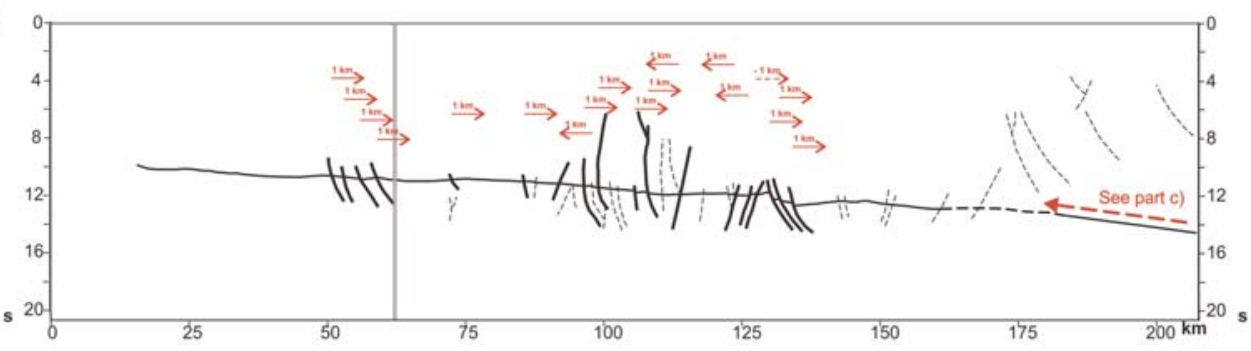

(c)

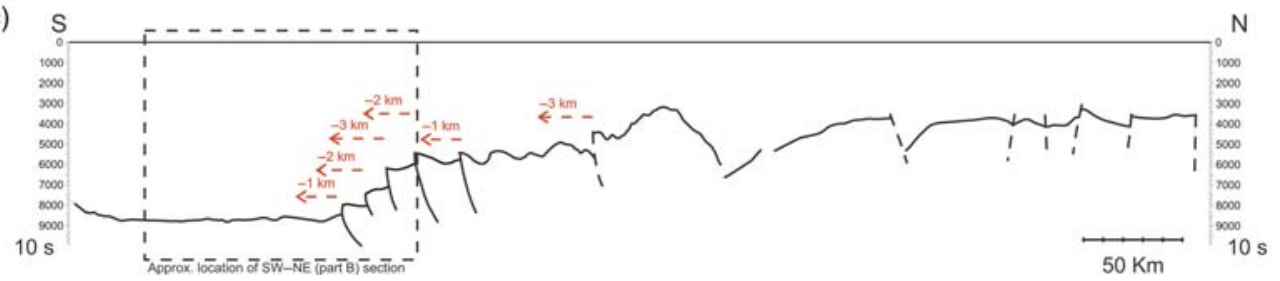

Fig. 9. (a) The SW-NE cross-sections from Figure $8 \mathrm{a}$ and $\mathrm{b}$ have been combined and depth-converted. (b) Quantification of fault deformation from composite section in (a). (c) Quantification of fault deformation from part of the SCB-Apsheron Sill-CCB composite section (Fig. 8c).

the thermal subsidence phase, combined with the sedimentary infill of accommodation, for a period of $150 \mathrm{Ma}$. The final phase of basin evolution is represented by the model in Figure 10c, which includes the effects of compressional deformation within the Apsheron Sill region. This compressional deformation is assumed to have occurred at $10 \mathrm{Ma}$, which approximates to the timing of the main uplift event identified onshore (Fig. 4). It has caused localized uplift of syn- and post-rift stratigraphic sequences in parts of the basin, whereas regions adjacent to the uplift have been deepened due to the crustal loading caused by the deformation. Model results show clearly that it is not possible to reproduce subsidence in the SCB with extensional and compressional deformation constrained by the magnitude of faulting apparent from the data. Maximum observed subsidence within the basin is over $20 \mathrm{~km}$, whereas the model shows a maximum depth of approximately $5 \mathrm{~km}$.

\section{Model scenario 2 - enhancing basin subsidence due to crustal attenuation}

A potential flaw with the modelling approach used to generate the models in Figure 10 is that the deformation, and therefore subsidence, predicted is constrained by the magnitude of fault-controlled deformation determined from the interpretation of seismic data. It is now acknowledged that crustal extension by fault displacement is much lower than overall crustal thinning in a variety of sedimentary basins (e.g. Moretti \& Pinet 1987; Driscoll \& Karner 1998; Kusznir et al. 2004). It is very likely, therefore, that the data interpretation presented in Figure 9 does not represent all of the deformation that has occurred within the SCB and, in particular, in the Apsheron Sill region where later compressional deformation will have caused the inversion of extensional faults. In other words, the extensional faulting observed today is 
(a) $\mathrm{s}$
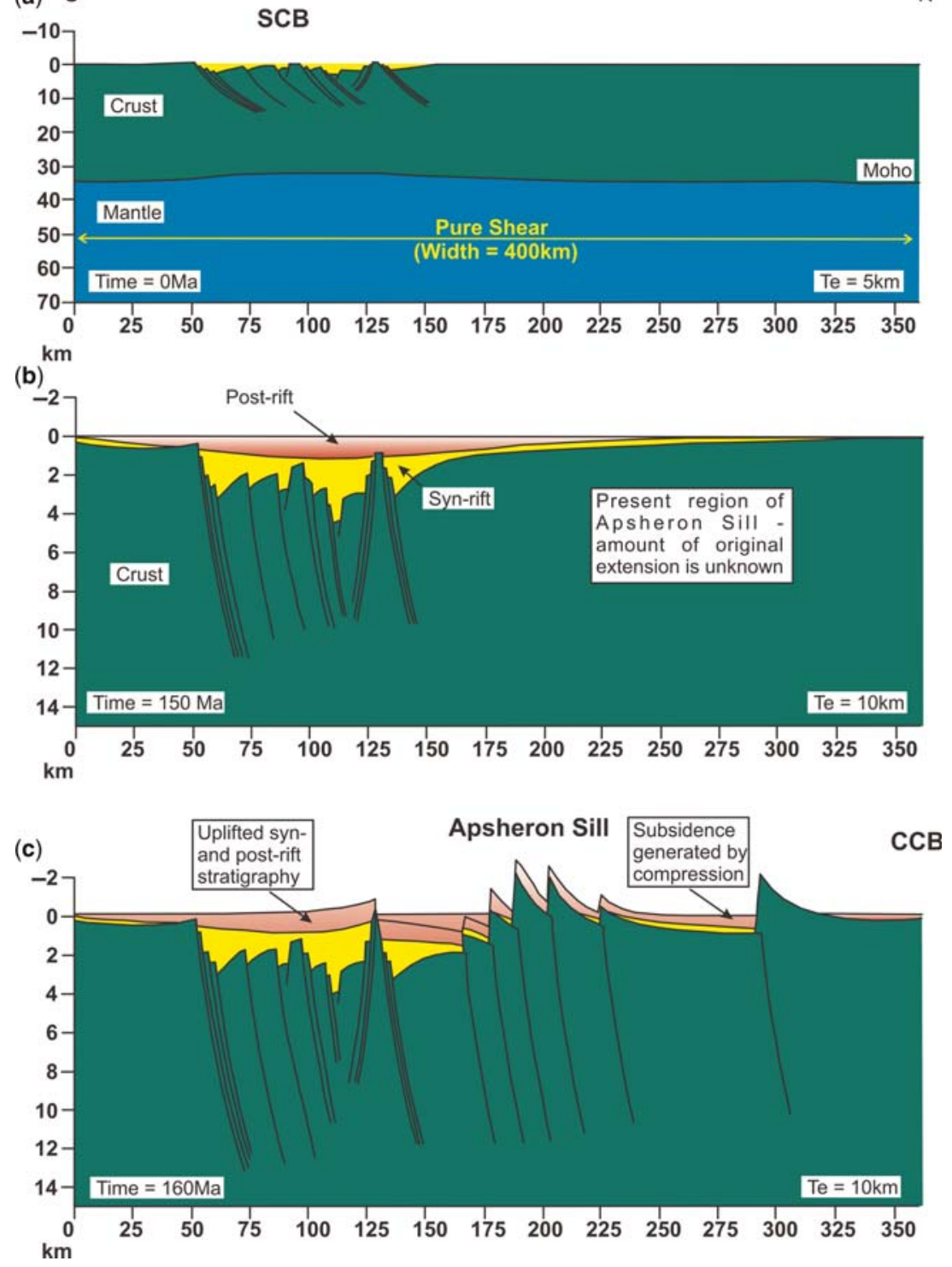

Fig. 10. Model representation of the SCB-Apsheron Sill region, assuming evolution is due to uniform lithosphere deformation. A sequence of model profiles are presented showing: (a) the initial rift phase; (b) the post-rift, thermal subsidence phase; (c) and the effects of compressional deformation.

only a fraction of that which occurred during the initial rift phase of the basin. In order to counter this potential problem, a modelling approach has been used in which the magnitude of deformation has been calculated using crustal thickness rather than basement faulting. An estimation of Moho depth based on published material (Mangino \& Priestley 1998) indicates that the crust beneath the $\mathrm{SCB}$ has been thinned to about $10 \mathrm{~km}$ along the line of section being considered. This equates to an extension factor (i.e. Beta value; McKenzie 1978) of 3.5, assuming an original crustal thickness of $35 \mathrm{~km}$. The model profiles presented in Figure 11 reconciles the magnitude of observed faulting with the overall thinning of the crust by assuming depthdependent stretching. The scenario modelled is one where the detachment or necking depth is allowed to progress towards the surface rather than being 
(a)

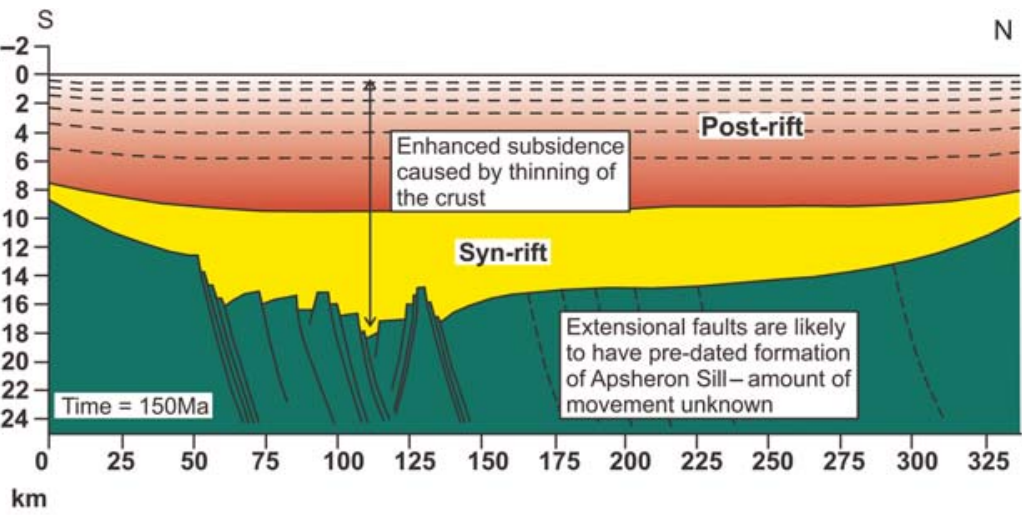

(b)

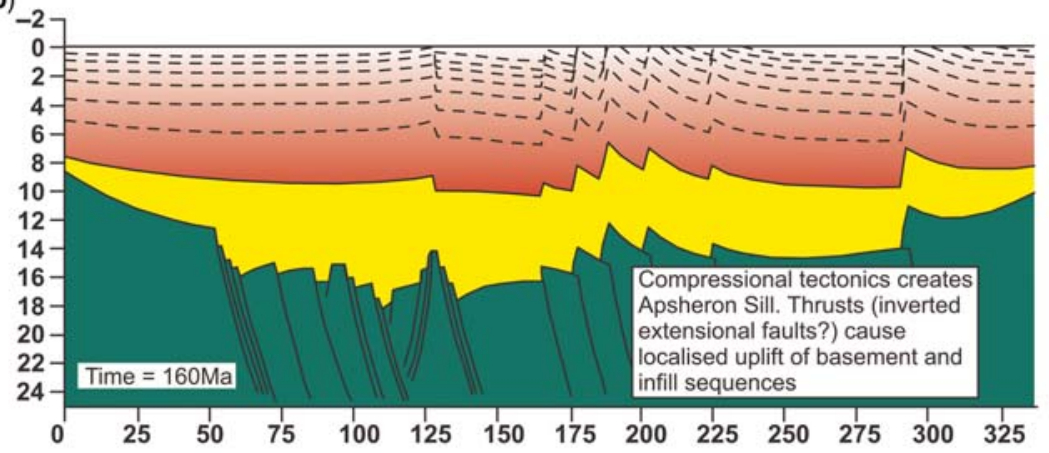

$\mathrm{km}$

(c)

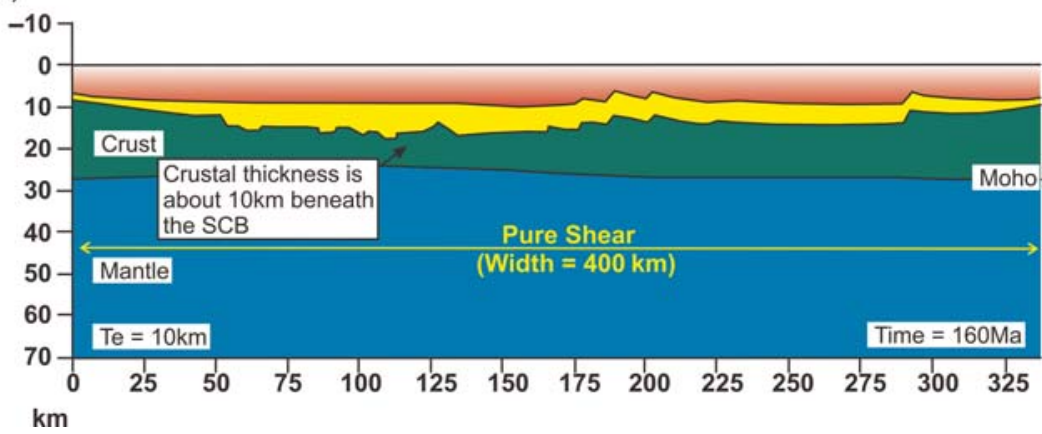

Fig. 11. Model profiles that reconcile the magnitude of observed faulting with the overall thinning of the crust by assuming depth-dependent stretching. (a) Extensional evolution of the basin showing syn- and post-rift sequences. Stratigraphic time lines within the post-rift sequence are at $20 \mathrm{Ma}$ intervals. (b) Compressional deformation to form the Apsheron Sill region. (c) As profile (b), but showing basin-fill sequences and the underlying lithosphere structure.

fixed at mid-crustal levels. The detachment zone may migrate throughout the evolution of a rift or during multiple rifts because the thickness of the brittle and ductile zones would change constantly during deformation in response to both the changing thickness of the crust and due to temperature perturbations (Kusznir \& Park 1987). The faulting configuration in the model is based on the regional sections presented in Figure 9, but extension has been increased in the lower crust and mantle lithosphere to reproduce a realistic attenuation of the crust. In response, the overall magnitude of subsidence has been increased to a maximum of $18 \mathrm{~km}$. In addition, the pattern of subsidence exhibited in this model is more similar to that exhibited by the real data, with a large thickness of post-rift 
(a)

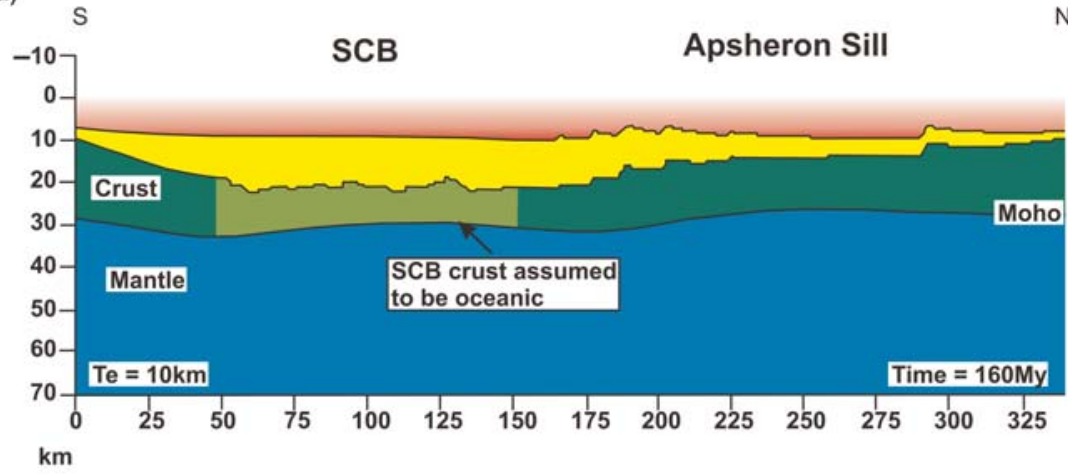

(b)

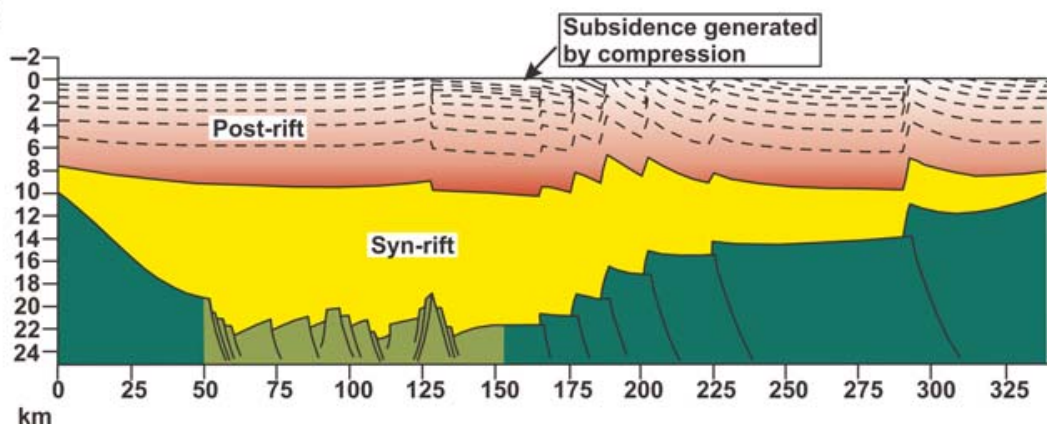

Fig. 12. Model profiles assuming that SCB crust is oceanic. (a) Profile showing basin, crust and upper part of the mantle lithosphere. (b) As profile (a) but showing basin-fill sequences and the top of the crust. The oceanic crust generates additional isostatic loading that results in a maximum basin depth of over $20 \mathrm{~km}$, which is very similar to that observed in the basin.

deposition relative to a thinner syn-rift phase. The model also includes compressional deformation (Fig. $11 \mathrm{~b}, \mathrm{c})$ to generate the Apsheron Sill region, which, like the previous model, has caused localized uplift adjacent to regional, flexurally induced subsidence.

\section{Model scenario 3 - enhanced subsidence due to oceanic crust}

The model results presented above have assumed that the crust beneath the SCB is continental in affinity, with a density of $2800 \mathrm{~kg} \mathrm{~m}^{-3}$. It has been suggested, however, that the SCB crust is oceanic (e.g. Brunet et al. 2003; Knapp et al. 2004), or a remnant of lower continental crust (Mangino \& Priestley 1998), which means that it may have a density of $3000 \mathrm{~kg} \mathrm{~m}^{-3}$ or greater. The model presented in Figure 12 is based on the same parameters and assumption as that in Figure 11; however, the thinned crust beneath the SCB has an increased density of $3000 \mathrm{~kg} \mathrm{~m}^{-3}$ that is compatible with oceanic-type crust. This density increase generates additional isostatic loading and, as a result, maximum basin depth is increased to over $20 \mathrm{~km}$ in the main part of the SCB, which is very similar to that observed in the basin.

\section{Model scenario 4 - subduction of South Caspian crust}

Several authors have presented convincing evidence that the crust beneath the SCB is being subducted beneath the Central Caspian region (e.g. Priestley et al. 1994; Knapp et al. 2004; Granath et al. 2007). This tectonic scenario has been modelled using the kinematic modelling approach described above. Figure 13a shows a model representation of the extensional evolution of the Caspian Basin. The model has been generated by extending the lithosphere by stretching over a width of $400 \mathrm{~km}$. Although it is acknowledged that the original width of the basin is open to debate, the current width of the basin in a NNESSW direction, between the Apsheron Sill and Iranian coastline, is about $325 \mathrm{~km}$. The results from gravity modelling carried out by Granath et al. (2007) suggests that a section of SCB crust 


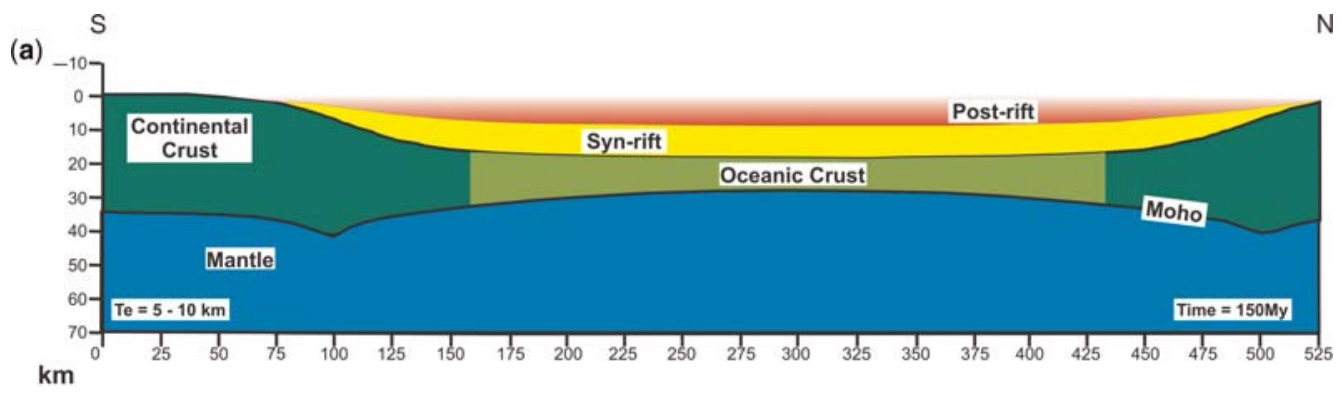

(b)

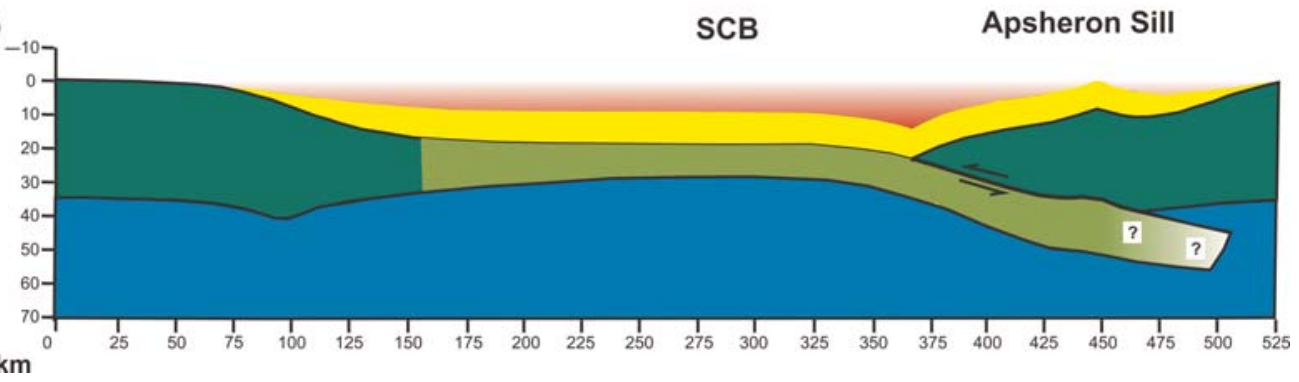

Fig. 13. Models showing the possible effects of the subduction of the SCB crust. (a) Model representation of the extensional evolution of the basin, which is assumed to be underlain by oceanic-type crust. The maximum basin depth is about $18 \mathrm{~km}$. (b) $80 \mathrm{~km}$ of subduction/under-thrusting of the SCB crust causes uplift of the basement, and synand post-rift sequences to form the Apsheron Sill. The adjacent basin has a depth of over $20 \mathrm{~km}$ due to isostatic loading generated by subduction and the infill of accommodation space.

at least $80 \mathrm{~km}$ in length has been under-thrust beneath the Central Caspian region. The original basin, therefore, must have been at least $400 \mathrm{~km}$ wide along the line of section being considered. The magnitude of extension included in the model has been gradually increased to thin the crust to $10 \mathrm{~km}$ (cf. original crustal thickness of $35 \mathrm{~km}$ ) beneath the central part of the basin. It has also been assumed that oceanic-type crust, with a density of $3000 \mathrm{~kg} \mathrm{~m}^{-3}$, exists beneath the basin compared to continental crust at the margins with a density of $2800 \mathrm{~kg} \mathrm{~m}^{-3}$. The basin has been allowed to thermally subside for a simulated time of $150 \mathrm{Ma}$ and any accommodation space has been filled to sea level with sediment with an average density of $2500 \mathrm{~kg} \mathrm{~m}^{-3}$. The maximum depth of the basin is about $18 \mathrm{~km}$.

The model presented in Figure 13b has assumed that an $80 \mathrm{~km}$-section of South Caspian crust has been subducted northwards beneath the central Caspian region, as proposed by Granath et al. (2007). The magnitude and timing of subduction of the northern SCB is open to debate. In the absence of definite information, subduction is assumed to have started at $10 \mathrm{Ma}$ to coincide with the main period of mountain building as evidenced from onshore data. The model results show relative uplift of basement, syn-rift and post-rift sequences over the Apsheron Sill, while the adjacent SCB is deepened to over $23 \mathrm{~km}$. The overall subsidence exhibited by this model shows the closest match to the observed subsidence indicated by the data interpretation presented in Figure 9, suggesting that the subduction of oceanic-type crust is a viable scenario to explain the evolution of the SCB.

\section{Discussion and summary}

Integration of the onshore and offshore components of the study reveals a more detailed picture of the tectonic and sedimentary events that have controlled the evolution of the Azerbaijan region of the SCB. Analysis of outcrop data within the eastern Greater Caucasus region reveals a succession of events that began with the deposition of sedimentary sequences within the basin environment at the southern edge of the Scythian platform during the middle Jurassic. These sequences are currently located within the central range of the Greater Caucasus mountain belt. The first evidence of compressional deformation is a Mid-Cimmerian unconformity that is represented by folded sequences of AalenianCallovian in age overlain unconformably by flatlying Callovian-Oxfordian carbonates and evaporites. There is another unconformity marking the 
end of the Jurassic period where tilted Kimmeridgian beds are overlain with erosive unconformity by Berriasian conglomerates. The lower Cretaceous is characterized by a sequence of olistolith deposits, suggesting ongoing tectonic processes at the edge of the carbonate platform forming the edge of the Scythian Plate. The mid-Cretaceous is marked by another folding event. All of these events occurred within the tectonic framework of back-arc extension related to the subduction of the Tethys Plate to the south beneath the Lesser Caucasus arc system. During this time period the SCB region was part of a much larger basin system, generally referred to as the Greater Caucasus basin or trough (Zonenshain \& Le Pichon 1986; Brunet et al. 2003), which was at least $300 \mathrm{~km}$ wide and $3000 \mathrm{~km}$ in length. The region was dominated by extensional tectonics interrupted by inversion events caused by regional plate movements and interactions.

The sequence of Mesozoic tectonic events that have been identified within the eastern Greater Caucasus are difficult to correlate directly with the evolution of the SCB. It is clear, however, from interpretations of the seismic data (Fig. 8) that the basement has been affected by extensional faulting which relates to the extensional regime that dominated the region at the time. It is not possible, however, to identify individual inversion events within the SCB. The sedimentary sequences of Mesozoic age within the basin typically occur at depths of over $10 \mathrm{~km}$ at which the resolution of the offshore data is not sufficient to identify relatively minor tectonic events. Although compressional deformation has affected Mesozoic and younger sequences in the basin, it is impossible to separate out episodes of deformation related to mountain building in the Tertiary from older events such as Mid-Cimmerian deformation. These events that are clearly identifiable onshore can be used as a proxy for the evolution of the adjacent basin.

During the Neogene period the basin system started to close in response to the collision between Arabia and Eurasia, leading to the main period of mountain building onshore. Folding and thrusting continues to the present day as evidenced by earthquake activity (e.g. Priestley et al. 1994) and progressive propagation of the thrust front at the southern leading edge of the orogeny (Philip et al. 1989). The mountain building has imposed a dominantly NW-SE structural trend on the region that is picked out by the axial surfaces of major folds, as well as cleavage development. The same structural trend continues into the SCB, most noticeably represented by the Apsheron Sill that effectively represents an offshore continuation of the eastern Greater Caucasus. The deeper part of the SCB also exhibits several other structural trends that can be related to onshore observations. In particular, the western part of the basin shows folding with a dominantly north-south orientation, which is compatible with fold structures of Pliocene age that can be observed onshore to the south and north of the main mountain belt. The offshore data also reveal a NE$\mathrm{SW}$-oriented sequence of uplift structures that are dominant in the eastern part of the study area. This structural trend can be identified throughout the whole mountain range as a system of large brittle faults that dissect the tectonic structures. These faults are readily seen on satellite images and are highlighted by the drainage pattern of the major rivers.

Structural and geodynamic modelling shows that it is not possible to explain subsidence in the SCB by uniform lithosphere extension when the magnitude of extension is constrained by the observed faulting of basement. This result is not surprising given the magnitude of mountain-building activity that has affected the Caspian region during the Tertiary period, which is likely to have inverted many of the extensional faults generated during the Mesozoic rift phase of the basin. In addition, Walsh et al. (1991) have shown that typically $10-40 \%$ of total fault-related extension may not be observed on regional-scale seismic profiles, a factor that is exacerbated in the SCB due to the relatively low data coverage of the basement structure. Model results indicate that it is necessary to combine faultcontrolled deformation with realistic thinning of the crust in order to reproduce a significant magnitude of subsidence. These models are based on a depthdependent stretching mechanism, which does present space problems caused by exaggerated stretching of the lower crust and mantle lithosphere (e.g. Rowley \& Sahagian 1986). A number of possible mechanisms may provide a solution to this apparent complication. For example, lower crustal flow has also been advocated as a mechanism for explaining the observed discrepancy between the amount of upper crustal extension due to faulting and extent of crustal thinning (e.g. Bertotti et al. 2000). In addition, Royden \& Keen (1980) have argued that magmatic intrusion into the crust may account for some of the inherent space problems, a mechanism that is compatible with the suggestion that the SCB is underlain by relatively dense, oceanic-type crust.

Although depth-dependent stretching greatly enhances basin subsidence, the mechanism alone fails to generate the high basin depths in parts of the SCB. It is suggested, therefore, that additional processes have played a role in enhancing the subsidence within the SCB. The preferred model for the region supports evidence derived from geophysical investigation, such that the SCB crust has a density that is compatible with either an oceanic composition or with thinned continental crust that has experienced transformation to a denser phase. 
This conclusion is also compatible with a similar modelling-based investigation carried out by Green et al. (2009). They have used a combination of flexural backstripping (Roberts et al. 1998) and forward kinematic modelling approaches to show that the majority of SCB subsidence can be accounted for by a combination of thermal subsidence and sediment loading of oceanic crust. They do not, however, take into account the effects of any late-stage compressional tectonics or subduction. Model results presented here suggest strongly that the subduction of South Caspian 'oceanic' crust beneath the central Caspian region is necessary to generate a realistic subsidence profile and geometry across both basin and the neighbouring Apsheron Sill. Clearly, there is scope for further investigation of these processes using modelling techniques, but any significant improvement on the results presented here requires constraint from additional offshore and onshore data.

We are grateful to the Middle East Basin Evolution Programme and its sponsors for funding this study from 2003 to 2005 . We would like to thank BP for providing access to offshore data for this investigation. Scientific collaboration with geoscientists at the Geological Institute of Azerbaijan-National Academy of Sciences (GIA) has proven invaluable in enhancing our understanding of the structural and stratigraphic evolution of the Greater Caucasus mountain belt. We also thank N. Abdullayev and F. Lucazeau for reviewing the manuscript and providing valuable suggestions for its improvement.

\section{References}

Allen, M. B., Vincent, S. J., Alsop, I. G., IsmailZadeh, A. \& Flecker, R. 2003. Late Cenozoic deformation in the South Caspian region: effects of a rigid basement block within a collision zone. Tectonophysics, 366, 223-239.

Ali-Zade, A. A., Khain, V. E. \& Ismail-Zade, A. D. 1999. The Saatly Ultra-deep Well. The Study of Deep Structure of the Kura Intermontane Depression According to the Data of the Drilling of the Saatly Ultra-deep Well SG-1. Nafta Press, Baku, (in Russian).

BARANOVA, E. P., KosminsKayA, I. P. \& PAVLENKOVA, N. I. 1991. A reinterpretation of south Caspian DSS data. Geophysical Journal, 10, 666-677.

Berberian, M. 1983. The southern Caspian: a compressional depression floored by a trapped, modified oceanic crust. Canadian Journal of Earth Sciences, 20, $163-183$.

Bertotti, G., Podladchikov, Y. \& Daehler, A. 2000. Dynamic link between the level of ductile crustal flow and style of normal faulting of brittle crust. Tectonophysics, 320, 195-218.

Brunet, M.-F., Korotaev, M. V., Ershov, A. V. \& Nikishin, A. M. 2003. The South Caspian basin: a review of its evolution from subsidence modelling. In: Brunet, M.-F. \& Cloetingh, S. (eds) Integrated
Peri-Tethyan Basin Studies (Peri-Tethys Programme). Sedimentary Geology, 156, 119-148.

Brunet, M.-F., Shahidi, A., B Arrier, E., Muller, C. $\&$ SAÏDI, A. 2007. Geodynamics of the South Caspian Basin southern margin now inverted in Alborz and Kopet Dagh (Northern Iran). In: European Geosciences Union EGU, General Assembly, Vienna, Austria, 1620 April. Geophysical Research Abstracts, 9, 08080.

Devlin, W. J., Cogswell, J. M. ET AL. 1999. South Caspian Basin: Young, cool and full of promise. GSA Today, 9, 1-9.

Driscoll, N. W. \& KARNER, G. D. 1998. Lower crustal extension across the Northern Carnaravon basin, Australia: Evidence for an eastward dipping detachment. Journal of Geophysical Research, 103, 4975-4991.

EGAN, S. S. 1992. The flexural isostatic response of the lithosphere to extensional tectonics. Tectonophysics, 202, 291-308.

Egan, S. S. \& Meredith, D. J. 2007. A kinematic modelling approach to lithosphere deformation and basin formation: application to the Black Sea. In: Karner, G. D., Manatschal, G. \& Pinheiro, L. M. (eds) Imaging, Mapping and Modelling Continental Lithosphere Extension and Breakup. Geological Society, London, Special Publications, 282, 73-198.

Egan, S. S. \& Urquhart, J. M. 1993. Numerical modelling of lithosphere shortening: application to the Laramide orogenic province, western USA. Tectonophysics, 221, 385-411.

Ershov, A. V., Brunet, M.-F., Korotaev, M. V., Nikishin, A. M. \& Bolotov, S. N. 1999. Late Cenozoic burial history and dynamics of Northern Caucasus molasse basin: implications for foreland basin modelling. Tectonophysics, 313, 219-241.

Ershov, A. V., Brunet, M.-F., Nikishin, A. M., Bolotov, S. N., Nazarevich, B. P. \& KorotaeV, M. V. 2003. Northern Caucasus basin: thermal history and synthesis of subsidence models. In: BRUNET, M.-F. \& Cloetingh, S. (eds) Integrated PeriTethyan Basin Studies (Peri-Tethys Programme). Sedimentary Geology, 156, 95-118.

GolonkA, J. 2000. Geodynamic evolution of the South Caspian Basin. In: Istanbul 2000, AAPG's Inaugural Regional International Conference, 9-12 July 2000. Istanbul, Turkey, Abstract Volume, 40-45.

GolonkA, J. 2004. Plate tectonic evolution of the southern margin of Eurasia in the Mesozoic and Cenozoic. Tectonophysics, 381, 235-273.

Granath, J. W., Soofi, K. A., Baganz, O. W. \& BAgIROV, E. 2007. Gravity modeling and its implications to the tectonics of the South Caspian Basin. In: Yilmaz, P. O. \& Is AKsen, G. H. (eds) Oil and Gas of the Greater Caspian Area. AAPG Studies in Geology, 55, 43-46.

Green, T., Abdullayev, N., Hossack, J., Riley, G. \& Roberts, A. M. 2009. Sedimentation and subsidence in the South Caspian Basin, Azerbaijan. In: BRUNET, M.-F., Wilmsen, M. \& Granath, J. W. (eds) South Caspian to Central Iran Basins. Geological Society, London, Special Publications, 312, 241-260.

Guest, B., Guest, A. \& Axen, G. 2007. Late Tertiary tectonic evolution of northern Iran: A case for simple crustal folding. Global and Planetary Change, 58, $435-453$. 
Guliyev, I. \& Feizullayev, A. 1997. All About Mud Volcanoes. Baku Publishing House, Nafta Press, Baku.

JACKson, J. A. \& MCKenzIE, D. P. 1983. The geometrical evolution of normal fault systems. Journal of Structural Geology, 5, 471-482.

Jackson, J., Priestley, K., Allen, M. \& Berberian, M. 2002. Active tectonics of the South Caspian Basin. Geophysical Journal International, 148, 214-245.

KANGARLI, T. 1982. Geological structures in the Azerbaijan lateral crest of the High Caucasus in geology-mineralogy. $\mathrm{PhD}$ thesis, Azerbaijan State University (in Russian).

Kazmin, V. G. 1991. Collision and rifting in the Tethys Ocean: Geodynamic implications. Tectonophysics, 196, 371-384.

Knapp, C. C., Knapp, J. H. \& Connor, J. A. 2004. Crustal-scale structure of the South Caspian Basin revealed by deep seismic reflection profiling. Marine and Petroleum Geology, 21, 1073-1081.

Knapp, J. H., Diaconescu, C. C., Connor, J. A., McBride, J. H. \& Simmons, M. D. 2000. Deep seismic exploration of the South Caspian Basin: lithospheric-scale imaging of the world's deepest basin. In: Istanbul 2000, AAPG's Inaugural Regional International Conference, 9-12 July 2000. Istanbul, Turkey, Abstract Volume. American Association of Petroleum Geologists, Tulsa, Oklahoma, 35-37.

Kooi, H., Cloetingh, S. \& Burrus, J. 1992. Lithospheric necking and regional isostasy at extensional basins. Journal of Geophysical Research, 97, $17,553-17,571$

Kusznir, N. J. \& EGAn, S. S. 1989. Simple-shear and pure-shear models of extensional sedimentary basin formation: Application to the Jeanne D'Arc Basin, Grand Banks of Newfoundland. In: TANKARD, A. J. \& BALKWILL, H. R. (eds) Sedimentary Basins and Basin Forming Mechanisms. AAPG, Memoir, 46, 305-322.

KUSZNIR, N. J. \& PARK, R. G. 1987. The extensional strength of the continental lithosphere: its dependence on geothermal gradient, crustal composition and thickness. In: Coward, M. P., Dewey, J. F. \& HANCOCK, P. L. (eds) Continental Extensional Tectonics. Geological Society, London, Special Publications, 28, 35-52.

Kusznir, N. J., Hunsdale, R. \& Roberts, A. M. 2004. Timing of depth-dependent lithosphere stretching on the S. Lofoten rifted margin offshore mid-Norway: Pre-breakup or post-breakup? Basin Research, 16, 279-296.

Kusznir, N. J., Karner, G. D. \& Egan, S. S. 1987. Geometric, thermal and isostatic consequences of detachments in continental lithosphere extension and basin formation. In: BEAUMONT, C. \& TANKARD, A. J. (eds) Sedimentary Basins and Basin Forming Mechanisms, Canadian Society of Petroleum Geologists, Memoir, 12, 185-203.

Kusznir, N. J., Marsden, G. \& Egan, S. S. 1991. A flexural cantilever simple-shear/pure-shear model of continental lithosphere extension: application to the Jeanne d'Arc basin, Grand Banks and Viking Graben, North Sea. In: Yielding, A. M. \& FreEman, B. (eds) The Geometry of Normal Faults. Geological Society, London, Special Publication, 56, 41-60.
MAMEdov, P. 1992. Seismostratigraphical investigations of geological structure of sedimentary cover of South Caspian superdepression and perspectives of oil-gas productivity. $\mathrm{PhD}$ thesis, Baku University (in Russian).

Mamedov, P. 2004. Genesis and seismic stratigraphic model of the South Caspian megabasin architecture. In: Ali-ZadeH, A. (ed.) South Caspian Basin: Geology, Geophysics, Oil and Gas Content. Special Issue Papers, 32nd International Geological Congress, Florence, Italy, 20-28 August 2004. Nafta Press, Baku $150-164$.

Mangino, S. \& Priestley, K. 1998. The crustal structure of the southern Caspian region. Geophysical Journal International, 133, 630-648.

McKenZIE, D. P. 1978. Some remarks on the development of sedimentary basins. Earth and Planetary Science Letters, 40, 25-32.

Moretti, I. \& Pinet, B. 1987. Discrepancy between lower and upper crustal thinning. In: BEAUMONT, C. \& TAnkARD, A. J. (eds) Sedimentary Basins and Basin Forming Mechanisms. Canadian Society of Petroleum Geologists, Memoir, 12, 233-239.

NAdirov, R. S., BAGIRov, E., TAGIYEV, M. \& LERCHE, I. 1997. Flexural plate subsidence, sedimentation rates, and structural development of the super-deep South Caspian basin. Marine and Petroleum Geology, 14, 383-400.

Philip, H., Cisternas, A., GVishiani, A. \& GorshKov, A. 1989. The Caucasus: an actual example of the initial stages of continental collision. Tectonophysics, 161, $1-21$.

Priestley, K., BAKer, C. \& JACKson, J. 1994. Implications of earthquake focal mechanism data for the active tectonics of the South Caspian Basin and surrounding regions. Geophysical Journal International, 118, $111-141$.

Reynolds, A. D., Simmons, M. D. ET AL. 1998. Implications of outcrop geology for reservoirs in the Neogene Productive Series: Apsheron Peninsula, Azerbaijan. AAPG Bulletin, 82, 25-49.

Roberts, A. M., Kusznir, N. J., Yielding, G. \& STYles, P. 1998. 2D flexural backstripping of extensional basins; the need for a sideways glance. Petroleum Geoscience, 4, 327-338.

Rowley, D. B. \& Sahagian, D. 1986. Depth-dependent stretching: A different approach. Geology, 14, 32-35.

RoYDEN, L. \& KEEN, C. E. 1980. Rifting processes and thermal evolution of the continental margin of eastern Canada determined from subsidence curves. Earth and Planetary Science Letters, 51, 343-361.

Sclater, J. G. \& Christie, P. A. 1980. Continental stretching: an explanation of the post mid-Cretaceous subsidence of the central North Sea basin. Journal of Geophysical Research, 85, 3711-3739.

Shikalibeily, E. S. \& Grigoriants, B. V. 1980. Principal features of the crustal structure of the SouthCaspian Basin and the conditions of its formation. Tectonophysics, 69, 113-121.

Shikalibeily, E. S., Abdullaev, R. N. \& Ali-Zade, A. 1988. Geological results of the super-deep well of Saatly. Sovetskaya Geologiya, 11, 61-66 (in Russian).

SNyder, D. B. \& HobBs, R. H. 1999. BIRPS Atlas II: A Second Decade of Deep Seismic Reflection Profiling. Geological Society, London. 
Turcotte, D. L. \& Schubert, G. 2002. Geodynamics. (2nd edn) Cambridge University Press, Cambridge.

van Wees, J. D. \& Cloetingh, S. 1996. 3D flexure and intraplate compression in the North Sea basin. Tectonophysics, 266, 343-359.

Verall, P. 1982. Structural Interpretation With Applications to North Sea Problems. Course Notes No. 3. JAPEC.

WALCOTt, R. I. 1970. Flexural rigidity, thickness and viscosity of the lithosphere. Journal of Geophysical Research, 75, 3941-3954.

Walsh, J. J., Watterson, J. \& Yielding, G. 1991. The importance of small-scale faulting in regional extension. Nature, 351, 391-393.
Weissel, J. K. \& Karner, G. D. 1989. Flexural uplift of rift flanks due to tectonic denudation of the lithosphere during extension. Journal of Geophysical Research, 94, 13,919-13,950.

White, N. J., Jackson, J. A. \& MCKenzIE, D. P. 1986. The relationship between the geometry of normal faults and that of the sedimentary layers in their hanging walls. Journal of Structural Geology, 8, 897-909.

Zonenshain, L. P. \& Le Pichon, X. 1986. Deep basins of the Black Sea and Caspian Sea as remnants of Mesozoic back-arc basins. Tectonophysics, 123, $181-211$. 